\title{
Las aceñas de acequia (islámicas) del sis- tema hidráulico andalusí de Murcia (Senda de Granada). Antecedentes tecnológicos y propuesta funcional
}

\author{
The (islamic) water-lifting wheels of the andalusi hydraulic system in Mur- \\ cia (Senda de Granada). Technological precedents and functional proposal
}

\author{
Luis A. García Blánquez*
}

\begin{abstract}
SUMARIO
La excavación arqueológica de un sector de la huerta de Murcia cercano a la ciudad, puso al descubierto un conjunto de estructuras hidráulicas andalusíes, junto a varios lotes de arcaduces tudmiríes que fechan los hallazgos entre el siglo X y finales del siglo XI o inicios del XII.

El hallazgo de estas estructuras islámicas sobre un contexto arqueológico tardoantiguo, reabrió en Murcia el antiguo debate sobre el posible origen preárabe de su sistema de riego, dando lugar a diversas interpretaciones acerca de sus antecedentes clásicos. Sin embargo, la conclusión del estudio de las estructuras, contextos estratigráficos y materiales han refutado aquella tesis, al menos respecto del heredamiento Norte (o de Aljufía), y confirmado nuestras hipótesis iniciales, en tres aspectos fundamentales: primero, la indudable filiación islámica de las estructuras hidráulicas documentadas y, en consecuencia, del sistema de irrigación del heredamiento Norte de Murcia; segundo, la extensión del perímetro de irrigación de esta parte del sistema hidráulico y su datación en el siglo X; y tercero, la primera identificación arqueológica en al-Andalus, de la que hemos denominado aceña de acequia, empleada para extraer agua de una acequia de riego a cielo abierto. Desde el punto de vista tecnológico realizamos una breve revisión de los modelos actuales y andalusíes y de su antecedente clásico la rueda extractora de tracción animal, representada en un monumento funerario de Kôm el-Dikka (Alejandría, Egipto). Finalmente, aunque no es el objeto de este estudio, los resultados arqueológicos relativos a su datación y extensión en el heredamiento Norte, nos permiten de forma indirecta hacer extensivas estas conclusiones al resto del sistema hidráulico murciano y al momento de su fundación, y plantear nuevas hipótesis acerca de su proceso de construcción.
\end{abstract}

Palabras clave: aceña/noria de tiro (sâniya, al-dûlâb, al-dawlâb), noria (naura), riego, cerámica islámica, arcaduz (qâdûs), al-Andalus, Mursiya, Kôm el Dikka, Alejandría.

\section{ABSTRACT}

The archaeological excavation of a section of the vegetable garden of Murcia near the city, laid bare in hydraulic andalusies' structures, along with several batches of buckets (arcaduz, qâdûs) tudmiries findings dates from the 10th and late 11th or early 12 th century.

The discovery of these Islamic structures and ditches on a late Antiquity archaeological context reopened in Murcia the old debate on the possible pre-Arab origin of its irrigation system, leading to different interpretations of its classical background. However, the conclusion of the study of hydraulic structures and stratigraphic analysis and material contexts have refuted that thesis, at least regarding North heredamiento (or Aljufía), and have come to confirm our initial hypothesis that can be synthesized on three main aspects: first, the undoubted Islamic affiliation of the canals and hydraulic structures documented and therefore the irrigation system in northern Murcia heredamiento; after that, the extent of irrigation perimeter of this part of the hydraulic system and its dating in the 10th century; and in the last place, the first al-Andalus' archaeological identification which we have called aceña of acequia, used to extract water from an irrigation ditch in the open.

From the technological point of view we made a brief review of Al-Andalus and current models and its classical antecedent wheel extractor of animal traction, represented in a funerary monument of Kôm el-Dikka (Alexandria, Egypt).

Finally, although not the subject of this study, archaeological findings regarding their dating and extension in the North heredamiento allow us indirectly to extend these findings to Murcia's rest of hydraulics and time of its "foundation", and raise new hypotheses about its construction process.

Key words: water-lifting wheels draught by animals (sâniya, al-dûlâb, al-dawlâb), water wheel (naura), irrigation, islamic pottery, bucket (qâdûs), al-Andalus, Mursiya, Kôm el Dikka, Alexandria

* ArqueoTec 


\section{EL YACIMIENTO DE SENDA DE GRANA- DA (ESPINARDO, MURCIA)}

El hallazgo fortuito de una sepultura tardorromana en el curso de las obras de urbanización en el Plan Parcial U.A. I ZA-Ed3 Espinardo (Murcia), puso al descubierto la existencia de un yacimiento del que no se tenía noticia previa y, por tanto, no se encontraba bajo control administrativo (Fig. 1).

\subsection{El medio físico}

Sus vestigios se extienden por una antigua zona de huerta, con un suave declive sursureste, organizada en dos terrazas articuladas por el curso antiguo de la acequia Alfatego. La septentrional, delimitada al norte a su vez por la acequia Churra la Vieja, se sitúa entorno de los 50/51 m de altitud sobre el nivel del mar ${ }^{1}$, mientras que en la meridional desciende desde los $49 \mathrm{~m}$ hasta los $45 \mathrm{~m}$.

Desde el punto de vista geomorfológico el emplazamiento arqueológico se ubica en el borde noroccidental de la llanura de inundación holocena del Río Segura, sobre una superficie inclinada hacia el sureste, que corresponde a los abanicos aluviales ligados a los sistemas de drenaje transversal de la red hídrica principal (río Segura)², formados por la rambla de Espinardo (también Mondexar) que transcurre al este, entre las calles de esta población, y la ya desaparecida de Los Lisones que confluía con la anterior en esta zona por el oeste.

El estudio sedimentológico ha constatado que el abanico aluvial de Espinardo se mantenía activo cuando la zona fue ocupada en época romana. Anteriormente la acción



Figura 1. Localización regional de Senda de Granada en Espinardo (Murcia)

1 En adelante aunque no se indique todas las medidas de altitud van referidas al nivel del mar.

2 Informe redactado por el geólogo F. Pérez Valera: "Estudio geológico y sedimentológico de los materiales sedimentarios relacionados con el yacimiento arqueológico <<Senda de Granada>>, Espinardo (Murcia)". 
erosiva remontante había modelado el frente del abanico aluvial creando un relieve de pequeñas lomas de escasa altura, surcadas por vaguadas intermedias poco profundas que, conforme avanzan hacia el sur, ganaban en amplitud dando paso a una planicie levemente inclinada hacia el sureste. El paisaje de la zona mostraba altozanos, probablemente amesetados, que fueron aprovechados para ubicar algunas construcciones de mayor envergadura, mientras que las zonas bajas intermedias albergaron áreas de trabajo, en tanto que en las llanas se instaló un hábitat de carácter muy modesto. Entre el abandono en época visigoda (en los inicios del s. VII) y el momento inicial de la ocupación medieval islámica, no se constata ningún proceso de aterramiento natural en la zona centromeridional, si bien posteriormente como con- secuencia de la instauración del sistema de irrigación se produjeron importantes aportes de limos acarreados por las propias acequias de riego que obligaron, incluso, a construir nuevos trazados para sustituir aquellos que quedaban entarquinados ${ }^{3}$.

\subsection{Fases de ocupación}

El sector excavado de Senda de Granada corresponde a la pars fructuaria de una probable villa rural romana que podemos datar entre el siglo IV y finales del siglo VI o principios del VII. El momento de su fundación queda impreciso, aunque la presencia de material cerámico residual (ss. I-III) localizado en algunos depósitos-vertedero bien fechados, sugiere que el enclave fue fundado hacia el siglo I de nuestra era (Fig. 2).

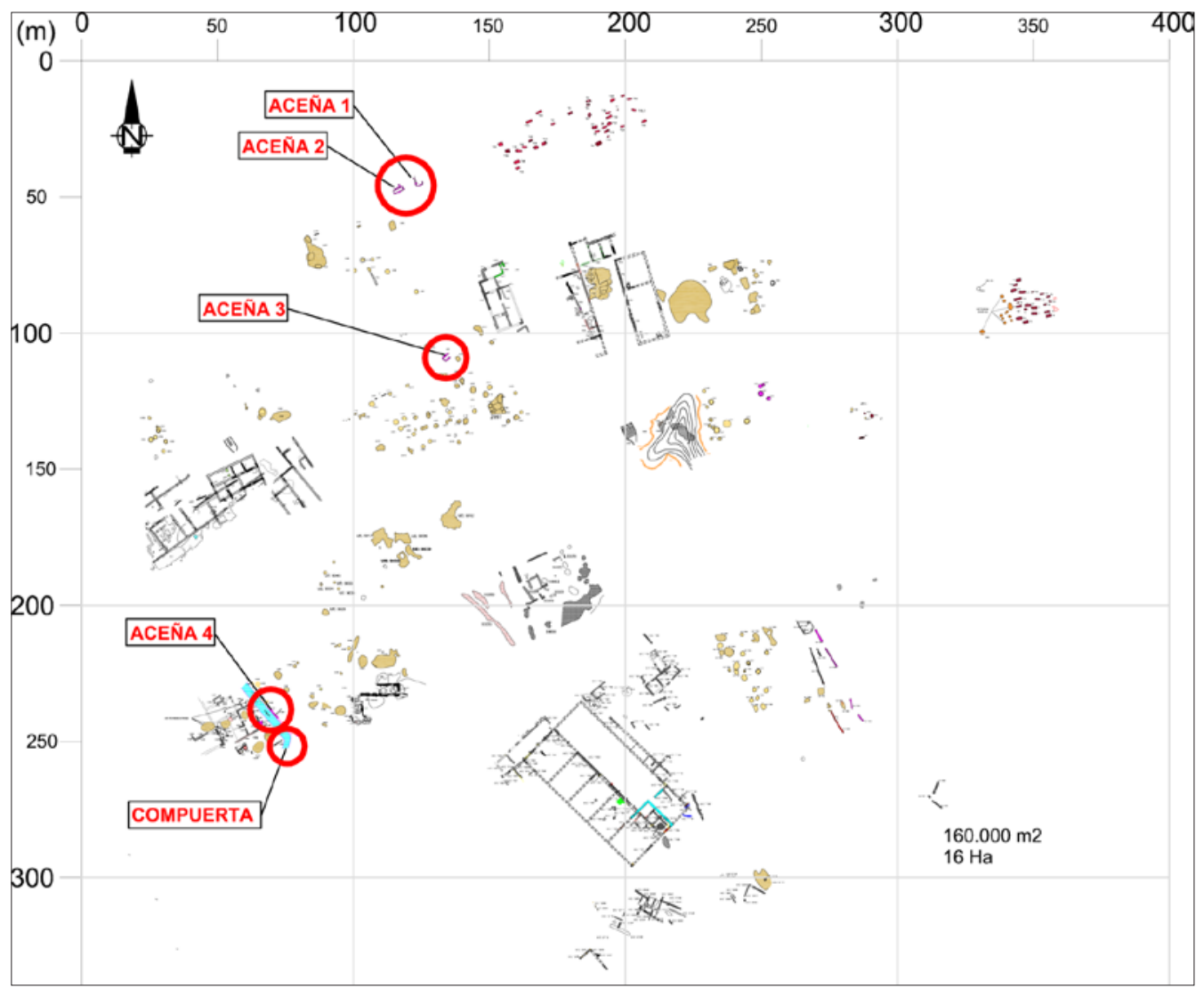

Figura 2. Planta acumulativa general del yacimiento tardoantiguo de Senda de Granada (Espinardo, Murcia) con indicación de las estructuras hidráulicas andalusies.

3 Término empleado repetidamente en las fuentes bajomedievales para indicar el súbito aterramiento de los cauces de las acequias y las parcelas de cultivo por lodos y limos aportados por las riadas (aguaduchos). Procede de tarquín, del árabe hispano, tarkím, y este del árabe clásico tarkìm, amontonamiento. Légamo que las aguas estancadas depositan en el fondo, o las avenidas de un río en los campos que inundan. D.R.A.E. edición actual (22. a), publicada en 2001 
Hacia finales del siglo V comienza un proceso de amortización y cambios de uso que se prolongará hasta mediados del siglo siguiente, durante el cual las instalaciones productivas comienzan a sufrir transformaciones incompatibles con su función inicial.

A principios del siglo VII, coincidiendo probablemente con la conquista y destrucción de la bizantina Carthago Spartaria a manos de los godos (Suintila/Sisebuto), este antiguo establecimiento tardorromano quedó definitivamente abandonado.

Tras el abandono a comienzos del siglo VII, el despoblado quedó expuesto hasta bien avanzado el siglo IX o, incluso, primeras décadas del X. Es en este momento cuando detectamos un conjunto de estructuras hidráulicas que transforman la zona en un espacio agrícola irrigado. Hacia la segunda mitad del siglo XII y principios del XIII, la zona o, mejor, su entorno inmediato, vuelve a ser poblado de nuevo, aunque de este espacio residencial sólo tenemos constancia de forma indirecta gracias a un pequeño grupo de silos que contenían algunos elementos constructivos y materiales domésticos de desecho.

El emplazamiento de la zona de residencia de la comunidad campesina islámica más próximo, cuya existencia deducimos sólo por la presencia de vajilla doméstica, debe localizarse en un punto cercano, quizás fuera del espacio irrigado, probablemente aguas arriba de la línea de rigidez. Así pues, todas las estructuras hidráulicas que se han documentado se construyeron desmantelando antiguas instalaciones productivas tardorromanas, o bien sobre los niveles de abandono de la ocupación tardoantigua. El área donde se construyen las aceñas 1 y 2, era un espacio sin estructuras que había dejado de frecuentarse hacia la primera mitad del siglo VI. La aceña 3 se instaló sobre una terraza que daba paso a una planicie repleta de silos, vertederos y áreas de combustión en uso desde finales del siglo IV hasta el siglo VI. Y la toma de la aceña 4 y el tablacho, estaban articulados por una acequia que seccionaba la parte oriental de una probable instalación aceitera.

La conquista cristiana (1243) y el reparto de tierras posterior, otorgaba a los mursies/mursyes árabes esta zona de la huerta murciana (heredamiento norte), permaneciendo en sus manos propiedades y derechos de explotación. Sin embargo, tras la revuelta mudéjar de 1264, la consiguiente pérdida de sus privilegios ocasionó el progresivo éxodo de la población musulmana. Hacia finales del siglo XIII o inicios del XIV la zona vuelve a quedar despoblada, sin que tengamos constancia material de la llegada de repobladores cristianos.

Finalmente, hacia mediados del siglo $X V I$, se hace palpable de nuevo la presencia humana en la cercana población de Torre de Espinardo ${ }^{4}$, situada al noreste de Senda de Granada. Y a mediados del siglo XVIII, el Catastro del Marqués de la Ensenada, nos informa de la continuidad del uso agrario instaurado por los árabes y su evolución posterior: "las tierras de esta villa son de Regadío y Secano, que en el Regadío las ay de Labrado Moreral, olivar, viñas y Frutales y en el Secano las ay de Labrado olivar montevajo y Inutil"...

\section{EL SISTEMA HIDRÁULICO EN SENDA DE GRANADA}

En esta zona el sistema de riego actualmente vigente está constituido por las acequias Churra la Vieja y Alfatego, situadas, respectivamente, al norte y en el centro de la zona de estudio que nos ocupa. Ambos cauces pertenecen al heredamiento norte del milenario sistema de riego de la huerta de Murcia (Fig. 3). Este sistema tiene su origen en

\footnotetext{
4 En el Repertorio de todos los caminos de España editado por Juan de Villuga en 1546, figura "Torre de Espinardo" en la ruta de Murcia a Toledo. Hacia 1542 el padrón de la parroquia de San Andrés de Murcia, de la que dependía Espinardo, ya contaba con 11 vecinos (http://geneaguerrero.es.tl)

5 Respuestas Generales del Catastro del Marqués de la Ensenada, Localidad: Espinardo, Provincia: Murcia. (AGS_CE_RG L463 480/487) Archivo General de Simancas (http://pares.mcu.es/Catastro)
} 


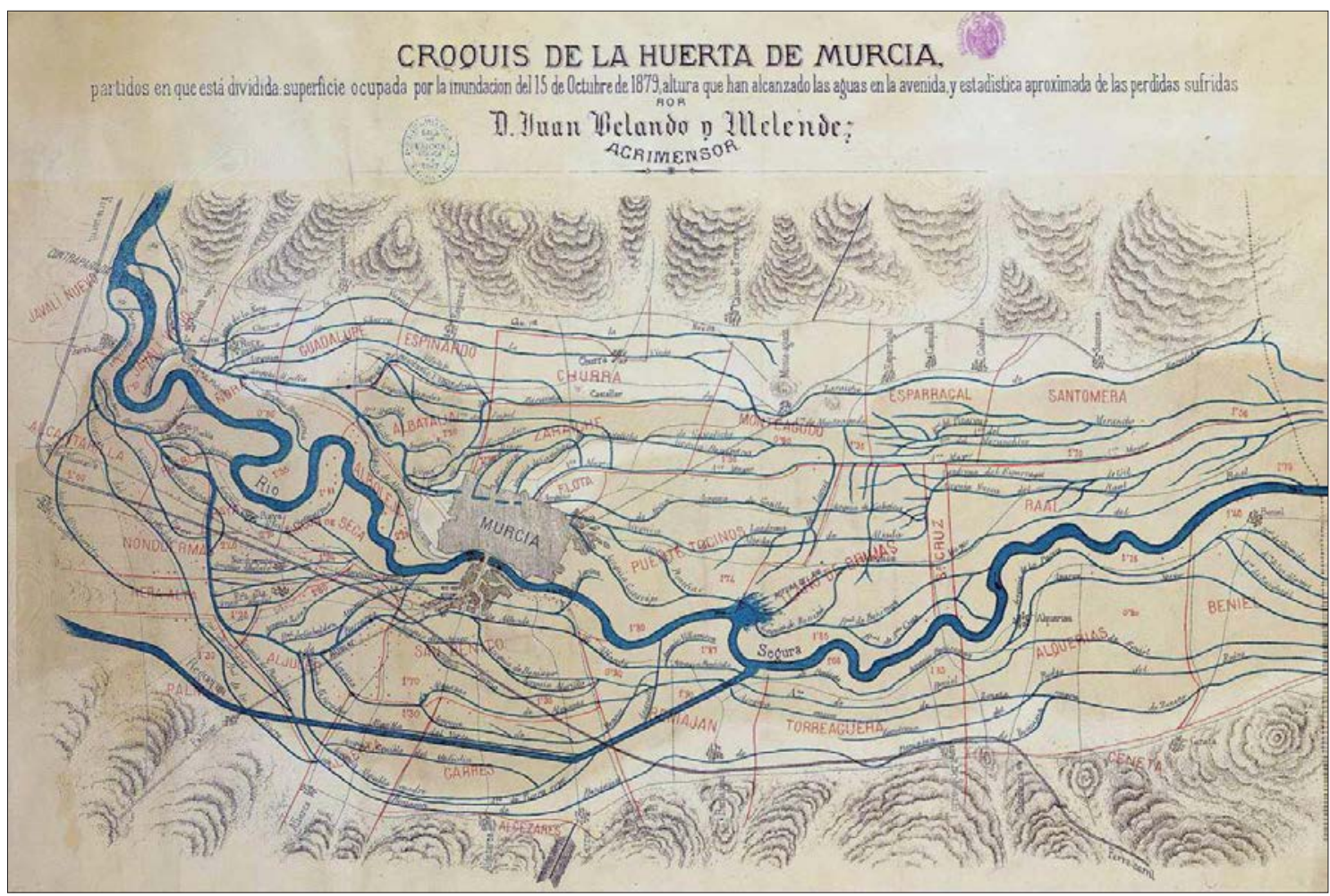

Figura 3. Esquema del sistema hidráulico de la huerta de Murcia a finales del siglo XIX, realizado por J. Belando y Meléndez con motivo de la riada de Santa Teresa (1879).

el denominado Azud Mayor de la Contrapara$d a^{6}$, situado en el río Segura a $12 \mathrm{~km}$, junto a la actual población de Javalí Nuevo (Murcia). En el azud Mayor y en la Contraparada tienen respectivamente su toma las acequias madre, arterias principales que abastecen cada uno de los sectores en los que queda dividido el regadío murciano: los heredamientos de Mediodía (Alquibla) y del Norte (Aljufía) ${ }^{7}$.

En la margen izquierda de la acequia madre de Aljufía toman agua, primero, la acequia Churra la Vieja y, unos metros más abajo, la acequia Alfatego (Fig. 4). Ambas acequias circulan en paralelo y a corta distancia entre sí (70/140 m) a su paso por la zona de estudio. Churra la Vieja transita por el norte cerca de la parte meridional de la población de Espinardo, con dirección NE y a una cota de 51/50 m de altitud; y Alfatego, desplazada algo hacia el sur, a un nivel inferior (49/48 m).

Además, el antiguo sistema hidráulico andalusí contaba aquí con un tercer canal de riego (Fig. 5), ahora amortizado, que denominamos provisionalmente acequia del Tablacho (correspondiente a un trazado antiguo de la acequia Alfatego), y un conjunto de estructuras hidráulicas singulares para regular el flujo, tomar agua y almacenarla: una compuerta o tablacho, tres aceñas y la toma de una cuarta.

6 La Contraparada es, junto con el azud Mayor y el Muro de Luzón, uno los principales elementos del complejo hidráulico y, seguramente, el más peculiar de todos ellos. Se trata de una estructura de vital importancia cuya función originaria era facilitar la entrada de agua en la acequia madre de Aljufía, a través de un canal excavado en la roca (s. XV) conocido como Riacho. La "contraparada" era en realidad una presa-aliviadero o presa-fusible, construida aguas arriba del azud Mayor, que ha terminado por dar su nombre a todo el conjunto hidráulico.

7 En 1877 el azud de la Contraparada regaba 102.088 tahúllas en la Huerta de Murcia y 6.479 tahúllas en la Huerta y término de Orihuela (en total 108.567 tahúllas), abarcando una extensión conjunta de 12.137 Ha (DÍAZ CASSOU, 1879: 59) 


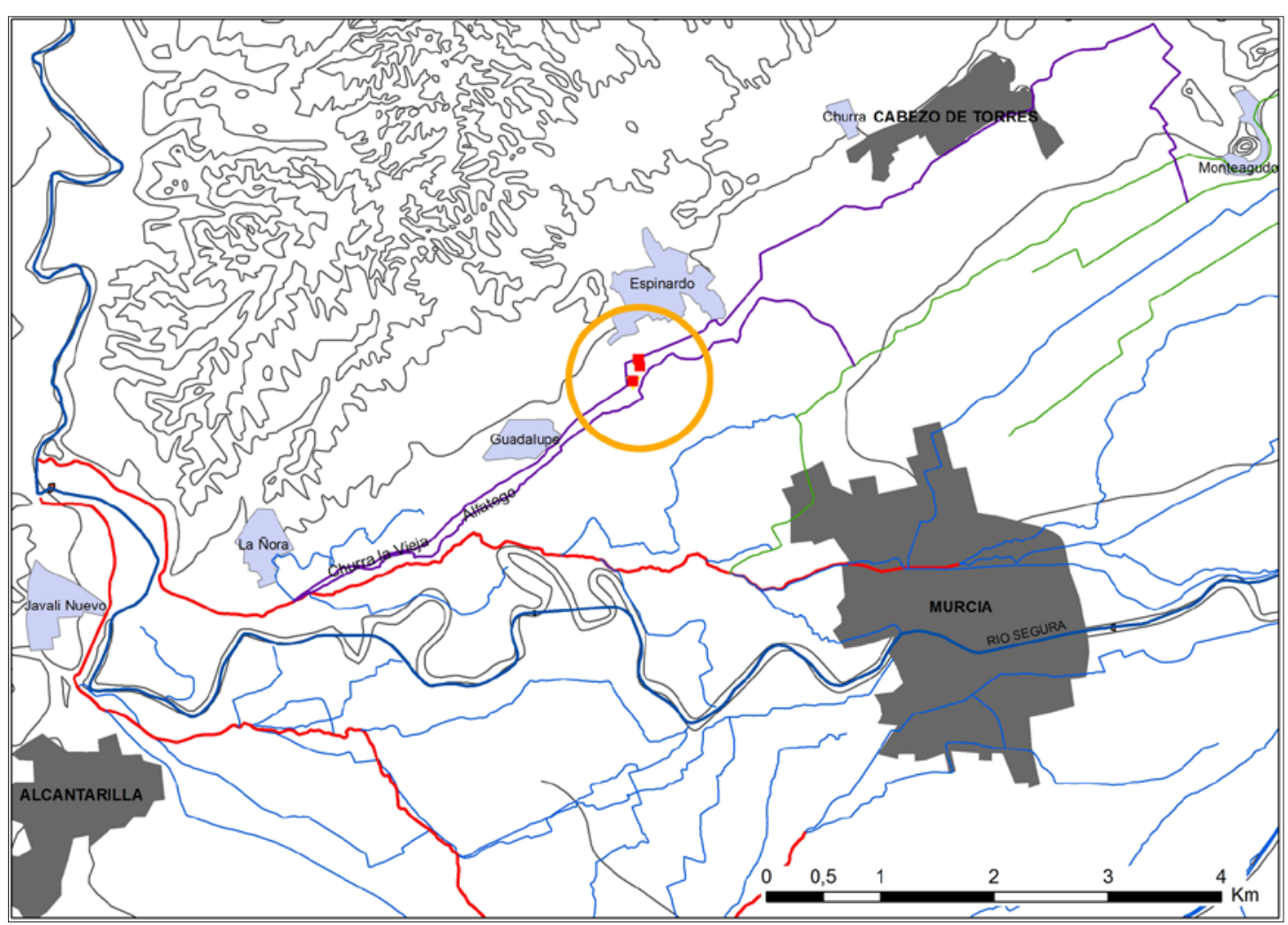

Figura 4. Localización de Senda de Granada entre las acequias Churra la Vieja y Alfatego en el heredamiento norte de Murcia. En rojo las acequias madre, en cian las acequias y en verde los azarbes.

\subsection{Las acequias}

\subsubsection{ACEQUIA CHURRA LA VIEJA}

Churra la Vieja8 es la primera derivación que nace por la izquierda de la acequia madre Aljufía (Fig. 4). Su toma es de carácter "abierto" y se encuentra en la población de La Ñora; de ahí se dirige hacia el este pasando por Guadalupe, la zona meridional de Espinardo ${ }^{10}$ y la población de Churra, donde, tras recorrer unos 9500 m, vierte sus aguas en el Azarbe de Monteagudo.

A su paso por la zona que estudiamos (Fig. 5), la acequia se encuentra soterrada y entubada, circulando con dirección SO-NE, siguiendo el trayecto actual de la calle Doctor de la Peña. Dado su estado actual y la imposibilidad de alcanzar su canal durante la excavación arqueológica, no nos fue posible conocer las características del cauce antiguo (forma, anchura, profundidad, obras de fábrica, procesos sedimentarios, etc.) y las respectivas tomas de las aceñas 1 y 2 . No obstante, si conocemos la cota de base de la conducción subterránea actual que en estos momentos se sitúa a 49,00 m de altitud, 0,69 m sobre el fondo constatado de la aceña 2; desnivel más que suficiente para que dichas artes se llenaran directamente por gravedad, aunque en época islámica éste fuera menor.

8 Según R. Pocklington el topónimo Churra ya existía antes de la Conquista cristiana y le atribuye un posible origen mozárabe (1990: 213-216).

9 Las acequias consideradas de "toma abierta" son aquellas que no tienen ni limitación ni turno de riego. Rafael de Mancha la describe así: "La acequia de Churra la Vieja que sale de la mayor de Aljufía al lado del norte, más arriba de la rueda de la Ñora, tiene abiertas su toma o boquera que en su solera consta 5 palmos y 6 dedos de ancho, recorre varias diputaciones regando en ellas 2653 tahúllas." (MANCHA, 1836: 27)

10 En 1836 Churra la Vieja regaba en Espinardo 297 tahúllas (MANCHA, 1836: 27). 


\subsubsection{ACEQUIA ALFATEGO}

La acequia Alfatego ${ }^{11}$ toma también por la izquierda de la acequia madre Aljufía pero, al contrario que Churra la Vieja, su toma es de tipo "cerrado"12. Su trayecto, de menor longitud que aquella (unos $6000 \mathrm{~m}$ ), discurre al sur, muy cerca y en paralelo a Churra la Vieja (Fig. 4). Desde La Ñora, se dirige hacia el este y, tras sobrepasar Guadalupe, Albatalía y Espinardo siguen con la misma dirección un corto trayecto, orientándose poco después hacia el sureste hasta la acequia de Zaraíche, donde vierte sus aguas sobrantes ${ }^{13}$, antes de alcanzar la población de Churra.

A su paso por el yacimiento (Fig. 5), la acequia circula con dirección SO-NE, aproximán- dose progresivamente a Churra la Vieja, hasta situarse en paralelo a ésta durante un corto trayecto $(70 \mathrm{~m})$, a partir del cual la acequia comienza a separarse hacia el sureste para describir un trazado arqueado que corresponde al relieve fosilizado de un derramador (abanico fluvial) localizado en el extremo distal de la rambla de Espinardo. El tramo del cauce que estudiamos discurre a cielo abierto. Su lecho se encuentra excavado en un depósito de tierra oscura de matriz areno-arcillosa, que constituye superficialmente lo que nosotros consideramos la tierra de labor cultivable de la huerta, asociada al regadío actual. Sin embargo, durante el proceso de excavación, hemos constatado que los sedimentos que forman el propio lecho y los quijeros ${ }^{14}$ están constituidos por arenas y limos de tonos gris-

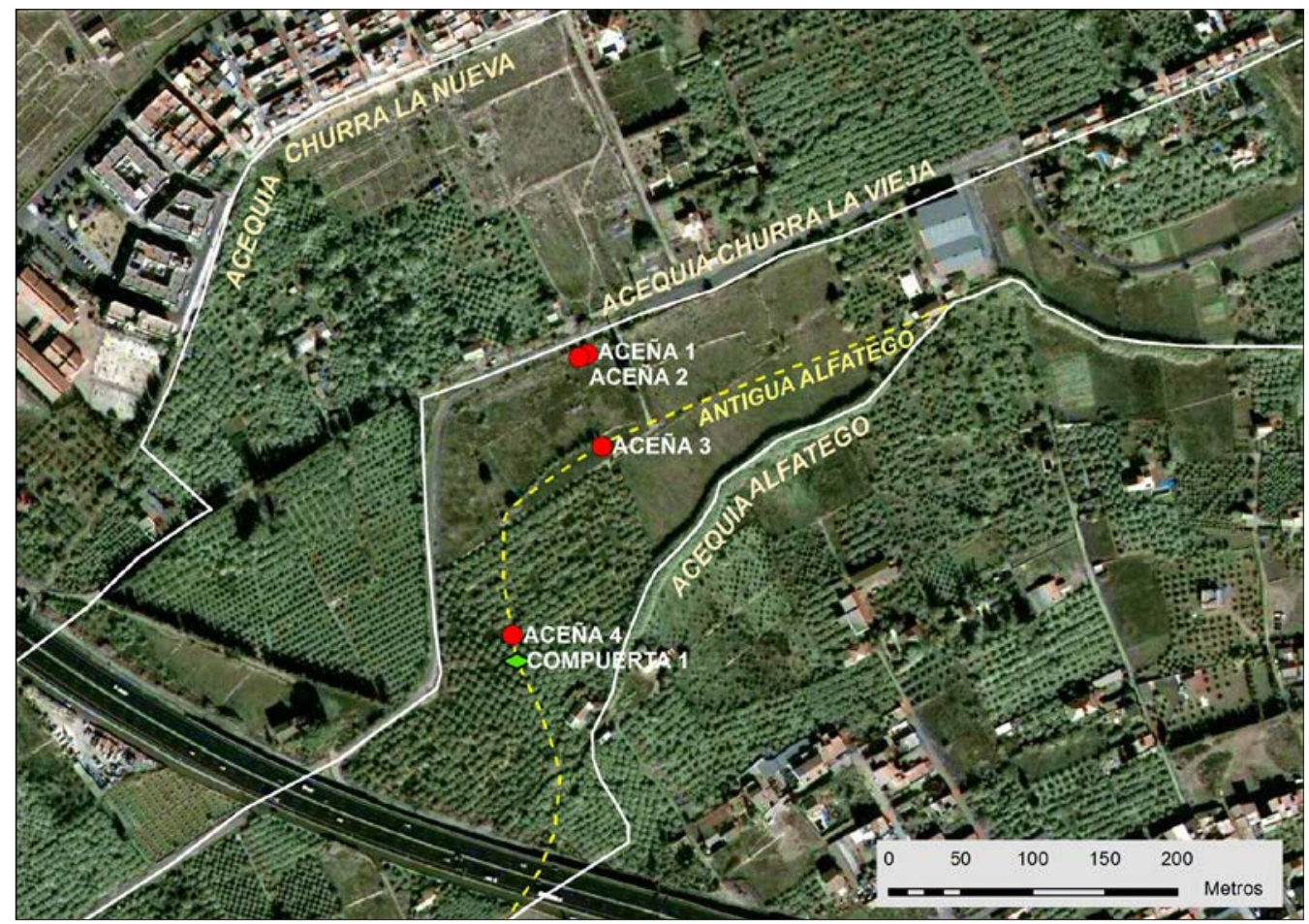

Figura 5. Localización de las estructuras hidráulicas (aceñas y compuerta) entre las acequias Churra la Vieja (norte) y Alfatego (sur), en un sector del heredamiento norte de la huerta de Murcia.

11 Alfatego es topónimo árabe. Aparece en la documentación escrita a finales del siglo XIV (TORRES FONTES, 1975).

12 Las acequias de "toma cerrada", en contraposición a las de "toma abierta", estás sometidas a una estricta regulación en cuanto al orden de sus regantes, el plazo y el tiempo de riego. R. Pocklington atribuye mayor antigüedad a la acequia Alfatego que a Churra la Vieja $(1990,165)$.

13 "La acequia de Alfatego que nace en la indicada acequia mayor (Aljufía) contigua de la anterior (Churra la Vieja), cuya boquera es un cuadrilátero de 2 palmos y 8 dedos de altura y de un palmo y nueve dedos de achura, y cuya cola cae en la acequia de Zaraíche, riega 1560 tahúllas...", 440 de ellas en Espinardo (MANCHA, 1836: 27).

14 "Quijero es el lado en declivio de una acequia: sirve para contener las aguas cuando se encumbran..." (Mancha, 1836, p. 19). RAE U 1817. (Pag: 722, 1): Mur. Lado en declive de la acequia o brazal. 
verdoso (acumulación y lixiviación de materia orgánica) que permite diferenciarlos perfectamente de los sedimentos limo-arcillosos subyacentes en los cuales se excavó el cauce. Así mismo se observa en la sección practicada en la acequia, la sucesiva acumulación de residuos en el fondo y la consiguiente elevación de su nivel de base, en el que se pueden distinguir hasta cinco lechos superpuestos, con leves desplazamientos del curso. El más antiguo y profundo es de forma cóncava, tiene 1,74 m de anchura máxima y una profundidad conservada en la parte central de 0,28 $\mathrm{m}^{15}$; a éste se superpone otro lecho con forma de cubeta, de mayor amplitud (2,36 m conservada) y profundidad parecida $(0,28 \mathrm{~m})$, al que le falta el quijero septentrional destruido por el cauce superior; el tercer lecho, también de forma cóncava, es el más ancho (5,5 m) y profundo de todos (4,94 m); el último de los lechos documentados, presenta sección en "V", con los márgenes rectilíneos, formando sus respectivos quijeros las motas actuales de la acequia.

\subsubsection{TRAMO ANTIGUO DE ALFATEGO (ACEQUIA DEL TABLACHO)}

Entre ambas acequias la excavación puso al descubierto varios tramos de un nuevo curso de agua del que no se tenía constancia, en el cual se documentaron la estructura de una compuerta (tablacho) y la toma de la aceña 4 (Fig. 5). Ni el relieve actual ni la cartografía clásica del regadío murciano permitía prever nada al respecto. Las secciones practicadas junto a estas estructuras hidráulicas pusieron de manifiesto, en ambos casos, que se trataba de un mismo canal cuya construcción amortizaba y afectaba una instalación productiva romana anterior (probablemente una almazara).

La sección tomada junto al tablacho ofrecía el registro estratigráfico del proceso de entarquinamiento de un canal de riego, hecho muy frecuente que causaba la inutilización y amortización definitiva de algunas acequias. La acequia que llamamos del tablacho, en este tramo fue excavado sobre un antiguo derramador de la rambla de Los Lisones, semejante al abanico citado del curso de Espinardo, formado por un lecho de arroyada de gravas y cantos. Estando en uso la acequia se rellenó de forma súbita con un potente nivel de limos arcillosos (tarquín) con piedrecitas, cuyo espesor (1,15 m) cubrió por completo la estructura pétrea de la compuerta, inutilizándola. Sobre este relleno, sin recuperar del todo el lecho anterior, se excavó otro. Más tarde, en este nuevo cauce, ya apenas cóncavo pero todavía en uso, se depositaron otras dos capas de relleno (de sendas riadas) formadas por arenas y cantos pequeños. El extraordinario aporte de sedimentos acarreados de una parte por la propia acequia (limos) y de otra por la rambla de Los Lisones (gravas y cantos) causaría el colapso definitivo del sistema hidráulico en esta zona. El cauce ya totalmente colmatado fue definitivamente abandonado transformándose en una nueva terraza de labor, ocasionando el ligero desplazamiento hacia el sur del amortizado curso del Tablacho que, en realidad, correspondía al trazado antiguo de la acequia de Alfatego que conocemos actualmente.

\subsection{Las estructuras hidráulicas de Senda de Granada}

Junto a las mencionadas acequias se documentaron también cinco estructuras hidráulicas: cuatro aceñas y una compuerta (tablacho) (Fig. 5). Junto al margen derecho de Churra la Vieja se disponen agrupadas las aceñas 1 y 2 que apenas distan entre sí 4,5 m (Fig. 6). La aceña número 3 se encuentra aparentemente aislada $60 \mathrm{~m}$ al sur de éstas. Y los demás elementos, la toma de la aceña 4 y la compuerta, situados a casi dos centenares de metros al suroeste de las primeras, se encuentran en el mismo lecho de la denominada acequia del Tablacho (tramo antiguo de Alfatego). 15 La anchura que ofrecemos de los cauces corresponde a la medición del espacio existente entre las partes más altas conservada
de los respectivos quijeros. La profundidad se mide en el centro del lecho respecto del quijero conservado más bajo 


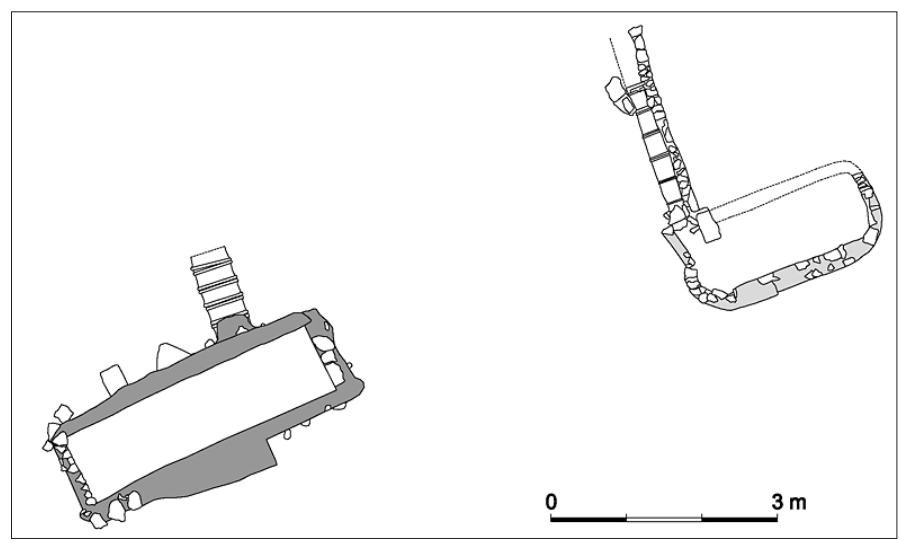

Figura 6. La aceña 1 (derecha) conserva parcialmente el pozo de extremos redondeados y el conducto de atanores cerámicos decorados. El pozo rectangular de la aceña 2 (izquierda) comunica con la acequia mediante un grueso conducto de atanores lisos.

\subsubsection{ACEÑA 1}

Está formada por un pozo y un conducto subterráneo (Lám. 1). El pozo de planta rec- tangular con los extremos redondeados tiene 2,36 m de largo por 0,78 m de ancho ${ }^{16}$. Su lado mayor meridional (falta el septentrional) está construido con una peculiar fábrica de


Lámina 1. La aceña 1.

1.- Pozo y conducto subterráneo de alimentación. 2.- Detalle del tramo de cañería hecho con atanores cerámicos decorados. 3-4.- Detalles de la fábrica del pozo con mampostería en espiga.

16 Coordenadas absolutas UTM ED50 30N de la intersección del conducto subterráneo con el lado septentrional: x: 661751, y: 4208142. 
mampostería tomada con argamasa de cal y los lados menores con piedra menuda y pequeñas lajas tomada con barro, formando una fábrica en espiga. El fondo está constituido por el propio substrato arcilloso sin ningún tipo de preparado.

En el vértice NO del pozo se abre un canal subterráneo de $3 \mathrm{~m}$ de longitud conservada, que se dirige hacia la acequia Churra la Vieja (dirección SE-NO), cuyo cauce se encuentra hoy día soterrado y entubado. Esta conducción, una sencilla atarjea ${ }^{17}$ excavada en el terreno, se compone de tres partes. El tramo de entrada al pozo está formado por un canalillo de $60 \mathrm{~cm}$ de longitud y 25/30 cm de anchura que, en su estado inicial, estaba cubierto con pequeñas lajas de piedra. La parte central es una cañería de 1,64 m de longitud formada por 5 atanores de cerámica de $30 \mathrm{~cm}$ de longitud y $26 \mathrm{~cm}$ de diámetro con refuerzos anulares en las embocaduras de $2 \mathrm{~cm}$ de grosor. Están decorados a peine con bandas onduladas y rectas incisas alternas $^{18}$. El flanco oriental de la zanja donde van colocados los tubos está protegido con un murete de piedra pequeña tomada con barro. El resto de la conducción hacia la acequia está excavada en el terreno pero no conserva la cañería ${ }^{19}$. Sólo su lado oriental está revestido con la misma obra que protege la cañería, excepto en su entronque con el canalillo donde presenta en el otro lado un pequeño refuerzo de piedra.

El interior del pozo estaba relleno de piedras y trozos de argamasa provenientes de la destrucción de sus propias paredes, entremezclados con fragmentos de arcaduces de noria de cuerpo cónico terminado en su base con un grosero y tosco botón irregular (Fig. 7, 1).

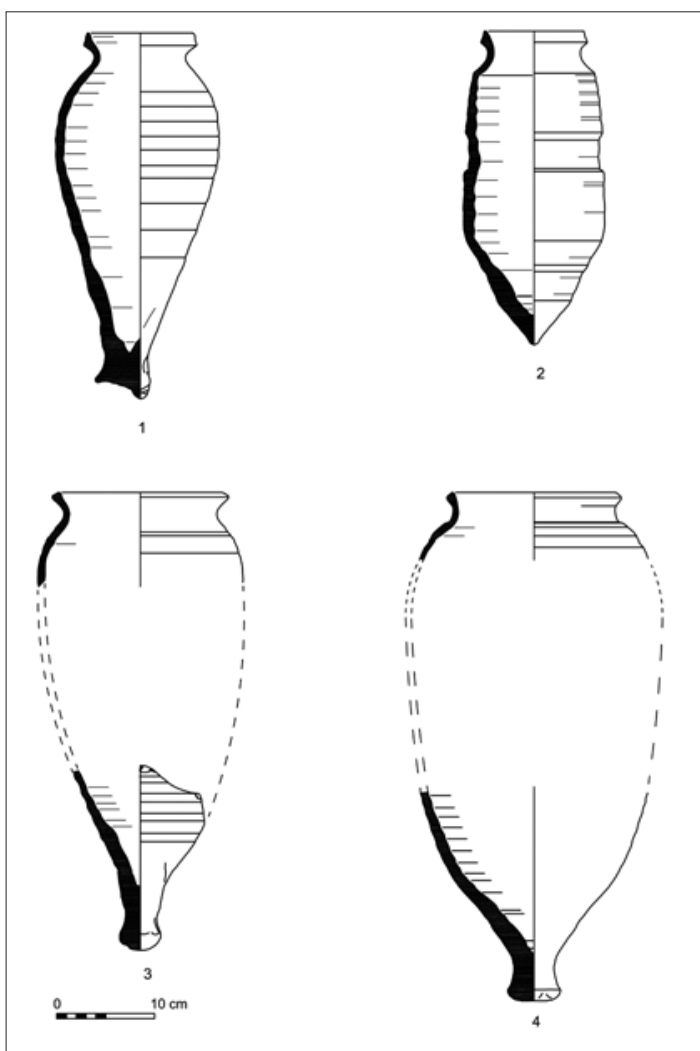

Figura 7. Arcaduces de Senda de Granada (Espinardo, Murcia): 1, 3, 4, arcaduz tipo I de amarre próximo-distal (SS. IX/X-XI); 2, arcaduz tipo // de amarre próximo-medial (ss. XII-XIII).

\subsubsection{ACEÑA 2}

Como la anterior, está compuesta por un pozo y una conducción subterránea20 (Fig. 6). El pozo de planta rectangular tiene $3,48 \mathrm{~m}$ de longitud por 0,9 m de anchura. Sus lados mayores (norte y sur) están construidos con tableros colocados contra el terreno, rellenos con mortero de cal y piedra de pequeño y mediano tamaño, de lo que resulta una buena fábrica de hormigón encofrado con cara regular y lisa hacia el interior del pozo e irregular por fuera. Los lados menores están levantados con mampostería cogida con mortero

17 Del árabe tarhiyya. F. atarjea. Obra de fábrica, pequeña, para dar paso al agua por debajo de un camino. RAE U 1979, P. 1237,3.

18 La decoración ondulada a peine, característica de las marmitas del siglo x, junto con la técnica constructiva del pozo confirmaría la datación antigua de esta aceña.

19 Este tramo del canalillo se dirige hacia la acequia Churra la Vieja situada fuera del área de excavación. El tramo visible tiene 0,7 $\mathrm{m}$ de longitud por 0,30 $\mathrm{m}$ de anchura, pero debía prolongarse al menos 1,5 m hasta alcanzar el lecho actual de la acequia.

20 Coordenadas absolutas UTM ED50 30N de la intersección del conducto subterráneo con el muro septentrional: x: 661745, y: 4208140. 
de cal, mostrando hacia el interior una mampostería ordinaria que ha perdido su revestimiento de argamasa (Lám. 2). Los muros tienen un espesor medio de 0,25/0,30 m, con algunos engrosamientos en los lados mayores $(50 \mathrm{~cm})$ que llegan hasta 0,60 m en el lado meridional. La fábrica del pozo no conserva su altura original, restándonos tan solo 1,05 m de su alzado ${ }^{21}$. El fondo está constituido por las mismas arcillas naturales, de color anaranjado, en las que se encuentran excavados y cimentados los muros perimetrales.

El conducto subterráneo parte de la cara septentrional del pozo de la aceña y se dirige con dirección NO hacia la acequia Churra la Vieja que discurre unos metros al norte, fuera del límite de la excavación. La parte visible de esta conducción está hecha con cinco anillos de cerámica ${ }^{22}$ colocados dentro de una pequeña zanja excavada en el terreno. La parte visible tiene 1,20 m de longitud. Cada pieza cilíndrica tiene $0,48 \mathrm{~m}$ de diámetro, $0,23 \mathrm{~m}$ de altura y $3 \mathrm{~cm}$ de espesor. Sus extremos están reforzados con bordes engrosados de sección cuadrada. Sus paredes externas son lisas y carecen de cualquier tipo de ornamentación. El primer anillo de la cañería está integrado en la fábrica del muro norte, cogido con argamasa, mientras que los demás aparecen ensamblados entre sí sin mortero. La parte superior de la cañería muestra un ligero declive de $3 \mathrm{~cm}$ hacia el pozo ${ }^{23}$. El nivel de base del conducto dentro del pozo se sitúa a 48,36 m, a escasos $5 \mathrm{~cm}$ encima del fondo arcilloso.
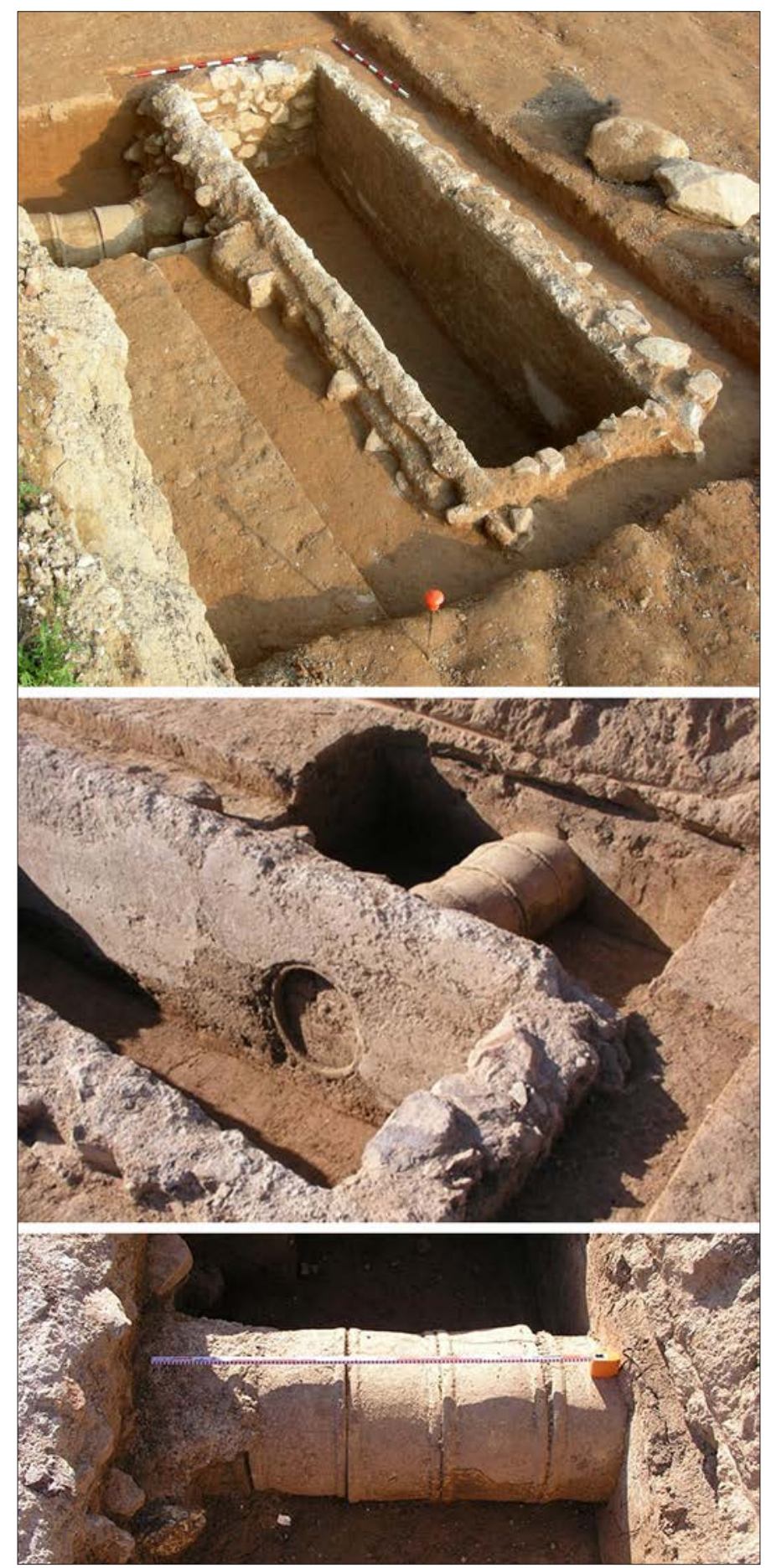

Lámina 2. La aceña 2. Arriba, pozo con fábrica de hormigón encofrado y mampostería, y conducto subterráneo de conexión con la acequia. Abajo: izquierda, detalle de la entrada de la cañería en la fábrica del pozo; derecha, detalle del conducto de cerámica de atanores lisos.

21 La cota más alta de la estructura conservada de la aceña se sitúa a 49,20 m.

22 Son similares a los que conocemos como anillos de pozo de aguas limpias documentados en las casas islámicas de Murcia. Véase al respecto RAMÍREZ y MARTÍNEZ 1996, y JIMÉNEZ CASTILLO 2013.

23 La inclinación constatada de $3 \mathrm{~cm}$ (48,84 m anillo N y 48,81 anillo S) en un trayecto de 1,20 m de longitud, supone una pendiente acusada (2,5\%), que haría circular a gran velocidad el agua por este conducto. 
El pozo se hallaba totalmente amortizado con abundantes restos cerámicos y grandes trozos de material constructivo. Los primeros están representados exclusivamente por fragmentos de arcaduces de gran tamaño, de cuerpo troncocónico y tendencia fusiforme, terminado en un grueso botón basal (Fig. 7, 3-4) (similares a los de la aceña 1).

Entre los restos constructivos encontramos trozos de fábrica de mortero de cal, piedras irregulares y dos grandes piezas labradas en piedra, que llaman la atención por su morfología y tipo de piedra, distinta al esquisto utilizado en la fábrica del pozo. Una de ellas, fabricada en caliza, tiene forma de vaso con las paredes rectas inclinadas, base plana y hueco interno en forma de cono invertido que llega a perforar la supuesta base. La otra es un sencillo sillar de calcarenita con un entalle en forma de "U" 24 .

\subsubsection{ACEÑA 3}

La aceña 3 (Lám. 3) conserva restos constructivos con dos tipos de fábrica diferente, cuya técnica podemos equiparar, respectivamente, a las documentadas en el conjunto septentrional (aceñas 1 y 2). La mitad sudoccidental del pozo se ha levantado con hormigón encofrado, mientras que el otro extremo se realizó con un tipo peculiar de mampostería en spicatum idéntica a la de la aceña 1.

En la mitad oriental del pozo se conserva esta peculiar fábrica de mampostería tomada con argamasa, caracterizada por el empleo de grandes placas de esquisto colocadas de cara y de hiladas irregulares de piedra de menor tamaño dispuesta en espiga ${ }^{25}$. Los restos de este paramento tienen 1,20 m de largo por 0,24 m de anchura máxima conservada. El resto de la estructura ha desaparecido casi por completo, aunque en las arcillas donde fue cimentada su impronta describe un trazado curvo en el extremo oriental y un lado recto en la parte meridional. En el extremo de este flanco se conserva un resto de su zócalo (de $0,36 \mathrm{~m}$ de anchura) al que se adosa el muro meridional de la otra fábrica. Las medidas internas de esta parte de la alberca serían 1,48 $\mathrm{m}$ de largo por 0,80/0,85 m de ancho.

El extremo sudoccidental se conserva en mejor estado. Los tres paramentos están hechos con hormigón encofrado. Definen una planta rectangular de 2,12 $\mathrm{m}$ de longitud por 1,10 m de anchura (medidas internas). Exceptuando el tramo meridional que está construido de forma exenta con doble cara (0,42 m anchura), los demás paramentos son lisos sólo por dentro ${ }^{26} y$ tienen espesor variable $27(0,25 / 0,40 \mathrm{~m})$.

\footnotetext{
24 Es probable que ambos elementos pétreos formaran parte de los componentes fijos de la aceña aunque estas piezas solían ser también de madera. Su dureza y resistencia al desgaste les hacía especialmente aptos para soportar grandes presiones y fricciones. Por ello, aunque estas piezas han aparecido desubicadas, les asignamos inicialmente este probable destino. La primera se podría relacionar con el eje vertical que, en el esquema funcional de una aceña clásica, correspondería al árbol de la denominada rueda de "tracción” o del "aire”. Quizás el bloque con su forma cónica invertida, se hallaría enterrado junto al pozo, servía para evitar el desplazamiento del peón al tiempo que obligaba a centrar su posición, facilitando el funcionamiento de una posible estructura poco ajustada o desvencijada. El bloque con forma de "U" cumpliría, probablemente, una función similar, aunque en este caso, como durmiente del eje horizontal de la "rueda del agua". Los dos resaltes laterales serían suficientes para que la chumacera (eje de la rueda vertical) no se desplazara fuera del entalle central, zona en la que se aprecia un mayor desgaste. No obstante debemos señalar que la función y ubicación precisa de esta pieza es aún más incierta, dado que en la cara contraria al rebaje advertimos una especie de retícula tallada que desconocemos su función. Es probable que este bloque haya sido reutilizado y su dibujo tan sólo tenga razones ornamentales y no prácticas. Thorkild Schiøler ha documentado en Jartum (Sudán) el empleo de durmientes de madera dura como apoyo del eje de la aceña, probablemente también de madera. Así mismo señala que la fricción de madera contra madera generaba un chirrido estridente que permitía escuchar al campesino, a gran distancia, si la aceña estaba trabajando http://www.kattler.dk/schiolers/uk/detaljer.html (fig. 125). Los autores andalusíes refieren este sonido de forma poética: "norias que deleitan con sus melodías..." (Risala fi fadl al-Andalus, elogio de la tierra andalusí y de sus habitantes, de Abul I-Walid al-Saqundi, m. 1232), "chirriantes norias..." (Hazim al-Qartaganni, m. 1286), "norias, cuyo ruido era como lamentos de añoranza..." (Safwan b. Idris, poeta y antólogo murciano de época almohade, 1165-1202) (CARMONA y POCKLINGTON, 2008: 36-37 y 61). Según los poetas, estas gratas melodías las emitían las norias (naura, pl. nawair) elevadoras de agua. Probablemente, la fricción de los ejes de las ruedas de la aceña (sâniya o dawlab) produciría un sonido semejante.

25 Esta estructura tiene 1,17 de largo por 0,24 m de anchura máxima conservada.
}

26 Los tableros de encofrar de los lados mayores conservan la impronta vertical del berenjeno que unía verticalmente las tablas horizontales.

27 La fábrica que rellena el encofrado se adapta por el exterior a la forma irregular del terreno que resulta al excavar el pozo. 


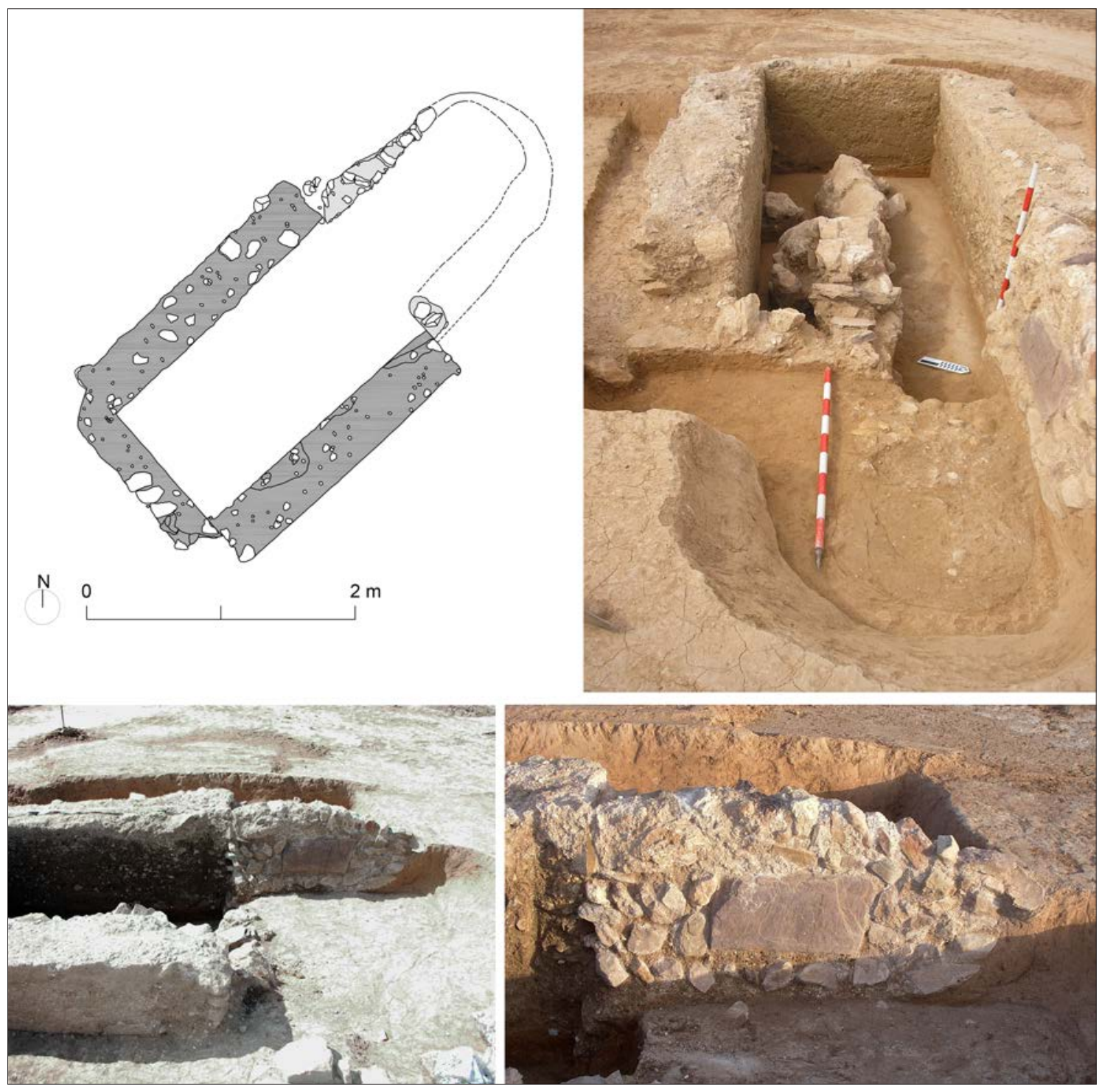

Lámina 3. Arriba, los restos de la aceña 3 conservan un tramo de la aceña antigua construida con fábrica de mampostería, al que se yuxtapone un tramo de hormigón encofrado, más reciente. Abajo: izquierda, vista frontal de la unión de los dos tipos de fábrica; derecha, detalle de la fábrica (antigua) en espiga con placa de esquisto.

Tampoco se conserva completo el alzado del pozo, del que sólo se ha podido documentar un tramo de 0,76/0,80 $\mathrm{cm}^{28}$ de altura de su parte más profunda. Las arcillas naturales, como en los casos anteriores, forman el fondo sin ningún otro tipo de revestimiento.

Respecto de la cañería subterránea y su entrada no hemos hallado indicio alguno, ni en el pozo ni en su entorno. La conservación íntegra de la parte occidental del pozo hace necesario que la acometida se hallara, si la tuvo, en el extremo oriental que falta, siguiendo el modelo de la aceña 2.

Como en los casos anteriores la estructura también se hallaba rellena con trozos de fábrica de los propios muros, piedras y gran cantidad de arcaduces fragmentados. Los arcaduces documentados aquí son diferen-

28 La cota superior de la fábrica se encuentra a 46,99m y su base a 46,36 m. 
tes, variando ostensiblemente su forma que pasa a tener cuerpo cilíndrico con escotadura central, borde vuelto, hombro carenado y base puntiaguda con perfil en ojiva (Fig. 7, 2). De forma minoritaria también se hallaron arcaduces similares a los registrados en la aceña 2, de cuerpo troncocónico, tendencia fusiforme y hombro redondeado, terminados en un grueso botón de tendencia esférica o cilíndrica.

Como vemos, los restos de la aceña 3 son el resultado de la yuxtaposición de los modelos de pozo documentados en las aceñas 1 y 2 , elaborados con técnicas y métodos constructivos diferentes: el de extremos redondeados con fábrica de mampostería en espiga y el de planta rectangular con hormigón encofrado. La diferencia estriba en que en el conjunto septentrional estos dos modelos se dan por separado, mientras que aquí forman una única estructura hidráulica. En el primer caso la aceña 1 fue probablemente sustituida por la 2, de mayor capacidad. En cambio, en la 3 se opta por su reconstrucción parcial, manteniendo en uso la parte antigua con la toma de agua todavía operativa. El resultado fue una estructura hidráulica de planta mixta, con un extremo recto y otro curvo de 3,60 m de largo por 1,08/0,8 m de ancho.

\subsubsection{ACEÑA 4}

Unos 150 metros al SO de la anterior se localiza la toma de la aceña número 4 , de la que sólo se conserva el conducto subterráneo que entronca con el muro de la acequia 29 (Lám. 4, 2). Se trata de un paramento encofrado de 4,27 $\mathrm{m}$ de longitud, 1,07 $\mathrm{m}$ altura y 0,45 m de anchura (orientación SE-NO), del que se conserva un tramo de dos cajones de largo por otros tantos de altura. Aunque sus respectivos extremos no muestran ningún tipo de terminación (mostrando la cal y el canto de su fábrica en contacto directo con el sedimento arcillo-arenoso que formaba la ribera de la antigua acequia) la estructura no parece estar truncada por ninguno de sus extremos (Lám. 4,1 ). Las caras del muro dejan ver una obra poco cuidada con los tableros del encofrado mal alineados, con amplias fisuras verticales y rebabas de mortero en la base de los cajones superiores. La cara interna del paramento muestra mayor descuido aún, dejando ver un berenjeno y alguna impronta del tableado ${ }^{30}$.

Al contrario que sucede en los casos anteriores (aceñas 1, 2 y 3), en esta ocasión se conserva la toma de agua situada dentro de la acequia y el conducto subterráneo, pero no el pozo de la aceña. La cañería está construida con atanores de cerámica similares a los de la aceña 1 , en este caso sin decorar ${ }^{31}$. El conducto soterrado conserva una longitud total de $3,73 \mathrm{~m}$, de los cuales $0,45 \mathrm{~m}$ se hallan bajo el muro y 0,58 $\mathrm{m}$ dentro de la acequia (Lám. 4, 3). En la fábrica del muro quedaron integrados atanor y medio y dentro del cauce otros tantos. En esta parte los tubos están recubiertos con argamasa, piedra y trozos de cerámica, mientras que la propia embocadura quedaba protegida lateralmente con sendos refuerzos de piedra y mortero (Lám. 4, 4), junto a la que se halló un fragmento de galbo de la parte inferior de un arcaduz de base apuntada y escotadura central.

En un momento indeterminado la acequia sufrió de forma repentina un proceso de sedimentación (entarquinamiento) colmatán-

\footnotetext{
29 Coordenadas absolutas UTM ED50 30N de la intersección del conducto subterráneo con el muro: x: 661699, y: 4207947.

30 Los cajones inferiores tienen 0,53 m de altura. En el meridional, de 1,93 m de largo, se encuentra encastrada la cañería cerámica. Para evitar su rotura por el peso de la fábrica, ésta descansa sobre un pequeño zócalo o zarpa, formado por una hilada de piedra tomada con mortero, que sobresale por ambas caras del paramento. El cajón septentrional, con 2,32 m de longitud, por el contrario, se asienta directamente sobre las arcillas de base. En la hilada superior los cajones invierten su longitud (2,34 y 1,91 $\mathrm{m}$, respectivamente). En ambas caras se conservan diversas improntas: por dentro, la marca semicircular de un berenjeno de 7 cm de ancho, y, por fuera, el tableado, cuya altura oscila entre 11 y $17 \mathrm{~cm}$. Finalmente, sobre el encofrado de cal se superponía un tapial de tierra, del que apenas se pudo comprobar su arranque en la parte meridional del paramento (una tongada de barro y otra de cal).

31 La longitud de los atanores oscila entre 0,31 y 0,34 m. El diámetro interno es de 0,26 m y sus embocaduras presentan refuerzos
} anulares de sección cuadrada. Están fabricados con arcillas de color amarillo, de textura rugosa poco compacta y quebradiza. 

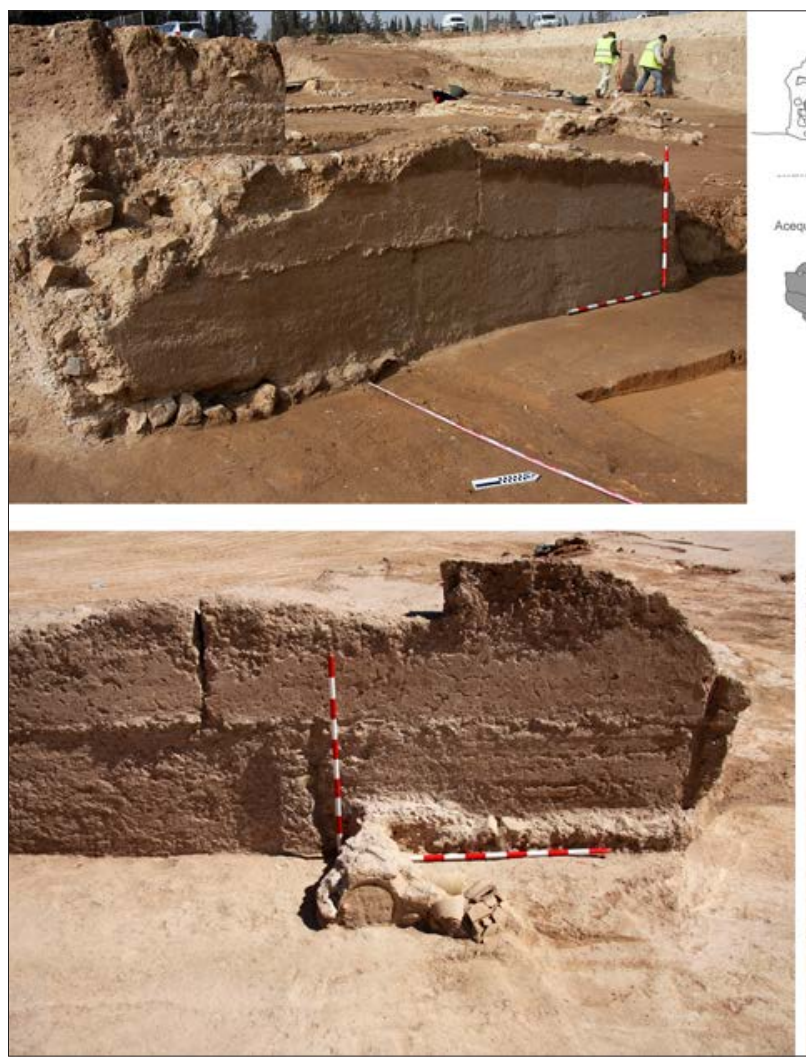

Lámina 4. La toma de la aceña 4 está formada por un muro encofrado integrado en el cauce de la acequia y un conducto subterráneo de atanores cerámicos que termina, dentro del cauce, en una embocadura reforzada con mampostería. 1. Detalle de la cara externa con arranque del conducto de atanores. 2. Planta, alzado y sección. 3. Detalle de la cara dentro de la acequia con la embocadura. 4. Vista cenital de la toma con los tubos protegidos con argamasa y piedras (derecha).

dose cerca de un metro de altura, cegando la embocadura. Posteriormente el cauce fue parcialmente re excavado liberando la embocadura, hasta que en otro episodio similar quedó finalmente inutilizada.

En el extremo opuesto la cañería se interrumpe sin solución de continuidad. La total ausencia de evidencias, sin rastro de estructuras, materiales de construcción o cerámicas, impide la reconstrucción de esta parte. No obstante, si consideramos que las estructuras conservadas aquí (toma y conducto) y en las aceñas 1 y 2 (conducto y pozo) pueden ser elementos complementarios, podemos admitir que la parte ausente corresponde al pozo de la aceña y su entronque con la cañería subterránea. La conjunción de las tres partes (toma, cañería y pozo) daría, pues, sentido estructural y funcional a lo que venimos denominando "aceña de acequia".

\subsubsection{COMPUERTA / TABLACHO}

Unas decenas de metros al SO, en el mismo cauce que la toma anterior, se localiza la compuerta/tablacho (Fig. 5). Está construida con cuatro bloques de piedra calcarenita: dos colocados en el umbral (de 0,98 cm de anchura) y otros tantos, en los lados, formando las jambas (0,44 m de altura conservada). Los bloques no están ensamblados con ningún tipo de fábrica; sólo se encuentran trabados en los márgenes del cauce o hincados en el fondo del lecho, que está formado por una capa de arenas, gravas y clastos de diverso tamaño ${ }^{32}$.

32 La estructura carece de material cerámico; sólo se halló en el mismo cauce (aguas arriba) un fragmento de galbo de cerámica esgrafiada. 
Aguas arriba del cauce (cara norte), la estructura se encuentra reforzada a ambos lados con bloques irregulares de menor tamaño ${ }^{33}$.

Las tres piezas que forman la compuerta están labradas sólo por dentro, mostrando una ranura de $4 / 5 \mathrm{~cm}$ de ancho por $4 / 5 \mathrm{~cm}$ de profundidad, entalle que formaba la guía donde se insertaba la compuerta o tablacho de madera, quedando el resto de la piedra sin ningún tipo de trabajo.

La estructura de piedra se sitúa en el fondo de un cauce ${ }^{34}$, con trayectoria SO-NE, excavado en un nivel natural de arcilla anaranjada de gran espesor que se extiende por toda la zona. Por encima el canal se hallaba totalmente colmatado por diversas capas sedimentarias de relleno integradas por lechos de limos, arenas y cantos, sobre las que finalmente se extendía una capa de tierra de labor anormalmente apelmazada.

\section{LAS ACEÑAS ACTUALES, SUS ANTECE- DENTES ANDALUSÍES Y EL PRECEDENTE ROMANO DE KÔM EL-DIKKA (ALEJAN- DRÍA)}

\subsection{Las aceñas recientes}

Las voces murcianas "aceña" o "ceña", como las catalanas "cinia" y "sinia", la valenciana "cenia" o la mallorquina "sini", provienen todas de la palabra árabe sâniya. Sabemos, sin embargo, por Ibn Hisham al-Lajmî (autor seviIlano del siglo XII) que el término correcto para designar a la noria de tiro (o de sangre) era, por el contrario, al-dûlâb o al-dawlâb, aunque entre los campesinos se había popularizado aquella voz (sâniya) que, realmente, sólo designaba al animal de tiro. Como señalan A. Bazzana y J. De Meulemeester (2009: 217) se trata de un problema lingüístico de resolución compleja, al que hay que añadir la variedad de términos empleados por otros autores árabes en relación con las diferentes partes ${ }^{35}$.

Las aceñas actuales son herederas directas del modelo islámico difundido por los árabes en el mediterráneo occidental hacia finales del siglo VIII36. Aquellos modelos fueron evolucionando y experimentando pequeñas adaptaciones que han terminado por caracterizar las máquinas hidráulicas en cada región del Mediterráneo.

El modelo genérico de aceña que ha perdurado hasta nuestros días, exceptuando dichas variantes regionales, consta de tres partes fundamentales: un pozo, un juego de dos ruedas engranadas y una plataforma circular (Lám. 5). Generalmente suelen estar acompañadas de una alberca o balsa para almacenar el agua antes de su distribución o, incluso, de un acueducto y, en ocasiones, también de un pequeño establo donde guarecer temporalmente los animales de tiro o el propio campesino. La rueda vertical, también llamada "noria" o "rueda del agua", es la portadora de la "cadena" o "rosario" de los arcaduces, es decir, la doble maroma en la que van atados los arcaduces o canjilones encargados de sacar el agua desde un manto freático subterráneo a la superficie ${ }^{37}$. A esta rueda se engrana la horizontal también conocida como "rueda

33 La posición de este refuerzo parece indicarnos la dirección de la corriente. Si el agua era retenida con el tablacho, el lado contrario (aguas abajo) debía soportar mayor presión.

34 Coordenadas absolutas UTM ED50 30N: x: 661702, y: 4207929. El umbral del tablacho se halla a 47,63 m.

35 Sobre la terminología árabe y la designación de las máquinas en al-Andalus véase: FÓRNEAS, 1974; MANZANO, 1986; BAZZANADE MEULEMEESTER, 2009, entre otros. D.R.A.E. edición actual (22a), publicada en 2001: Aceña. Del árabe hispánico assánya, y este del árabe clásico sāniyah "elevadora" 1. f. Molino harinero de agua situado dentro del cauce de un río. 2. f. azud ( $\square$ máquina). 3. f. espadaña (planta tifácea). Cenia. (Del ár. hisp. assánya, y este del ár. clás. sāniyah, elevadora). 1. f. Azud o máquina simple para elevar el agua y regar terrenos, muy usada al norte de la provincia de Valencia. 2. f. En Marruecos, noria (| máquina para subir agua). 3. f. En Marruecos, huerto o jardín que se riega con este artefacto. Ceña. (Cf. aceña).1. f. Mur. noria (máquina para subir agua). En las fuentes medievales de Murcia, aparece bajo las formas "açenna", "acenn(i)a", "açenia", "zenia".

36 No se tiene constancia de restos arqueológicos (estructurales o materiales) que se puedan atribuir con certeza a máquinas hidráulicas extractoras de agua con ruedas engranadas movidas por tracción animal.

37 Llamamos "rosario" a la cuerda sin fin en la que van atados, a trechos, los arcaduces. Este largo cable, que va montado en la noria vertical, se emplea cuando el agua del pozo se encuentra a gran profundidad. 


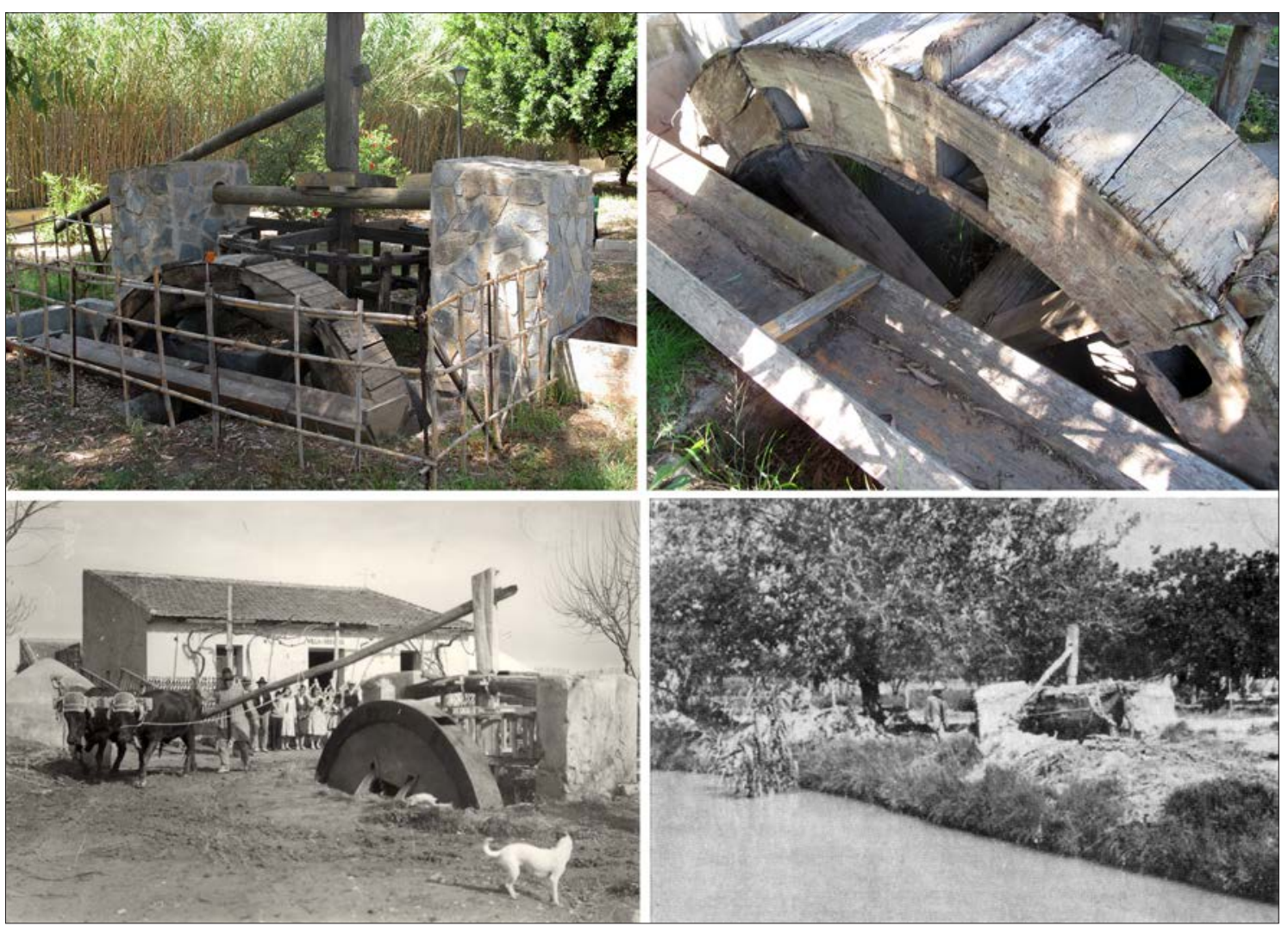

Lámina 5. 1. Reproducción a escala real de la aceña huertana (Museo Etnológico de la Huerta de Murcia). 2. Detalle de los cangilones de la aceña huertana. 3. Rueda de ceñil aplicada a una aceña (Archivo CHS). 4. Aceña de acequia en su emplazamiento natural en la huerta de Murcia (TORRES FONTES,1990: 94)

del aire", de "tracción" (CARO BAROJA, 1983: 359) o "contra-rueda" (MONTANER SALA, 1982: f. 17). El pozo de la noria, de planta alargada con los extremos rectos o redondeados, suele estar revestido con mampostería ordinaria y en raras ocasiones, la parte más profunda del foso queda desnuda para facilitar el paso del agua. El calado es también variable, dependiendo del nivel donde emerge el agua, en ocasiones a más de $10 \mathrm{~m}$ de profundidad. La fuerza motriz de origen animal, transmite el movimiento de rotación a la rueda de tracción o del aire y ésta, mediante un sencillo engranaje, a la vertical consiguiendo elevar el agua desde el fondo hasta la superficie donde suele conducirse hasta una alberca o balsa de almacenaje, o bien, por un canal de riego directamente a las parcelas de cultivo. El animal, uncido a la pértiga (o "malacate") que mueve el eje de la rueda de tracción, discurre con una trayectoria circular sobre una plataforma llamada "andén", delimitada con un murete bajo perimetral. Por razones obvias, la plataforma de estos ingenios hidráulicos debe ocupar siempre un lugar alto respecto del terreno circundante o, en su defecto, sobre elevado artificialmente, dado que el agua tras su extracción debe circular sólo por gravedad. Este promontorio artificial, generalmente un simple relleno, se reviste perimetralmente con mampostería para evitar el desmoronamiento de los taludes de tierra. En la comarca de Mazarrón (Murcia), los promontorios artificiales de las aceñas se caracterizan por su extraordinario desarrollo en altura, que exige la colocación de un revestimiento de mampostería muy robusto dotado, incluso, de contrafuertes de fábrica, que les confiere el aspecto de torreones defensivos motivo por el que se denominan aceñas "fortificadas" (MONTANER SALAS, 1982: 64) (Lám. 6). 


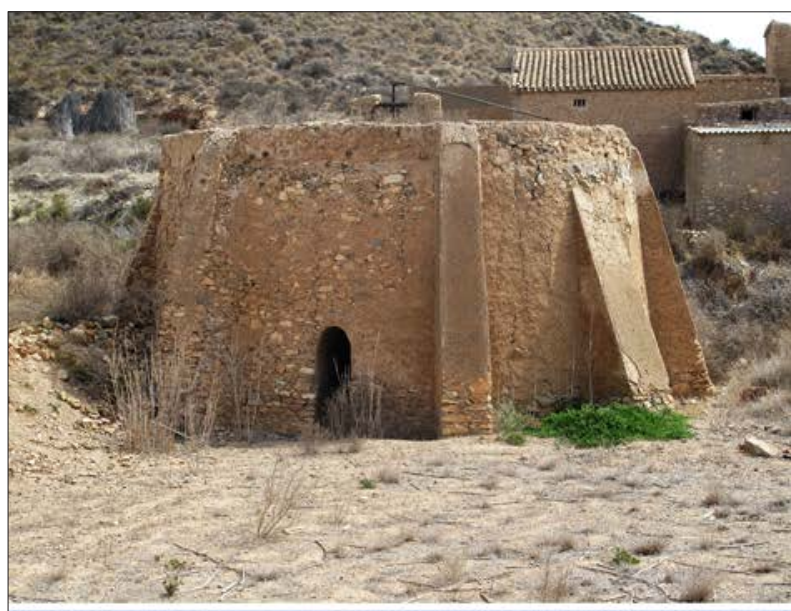

Lámina 6. Ejemplos de aceñas "fortificadas" de la comarca de Mazarrón (Murcia) en las que la gran elevación del promontorio requiere de un revestimiento de mampostería muy robusto dotado, incluso, de contrafuertes de fábrica (Fotografía ArqueoTec).

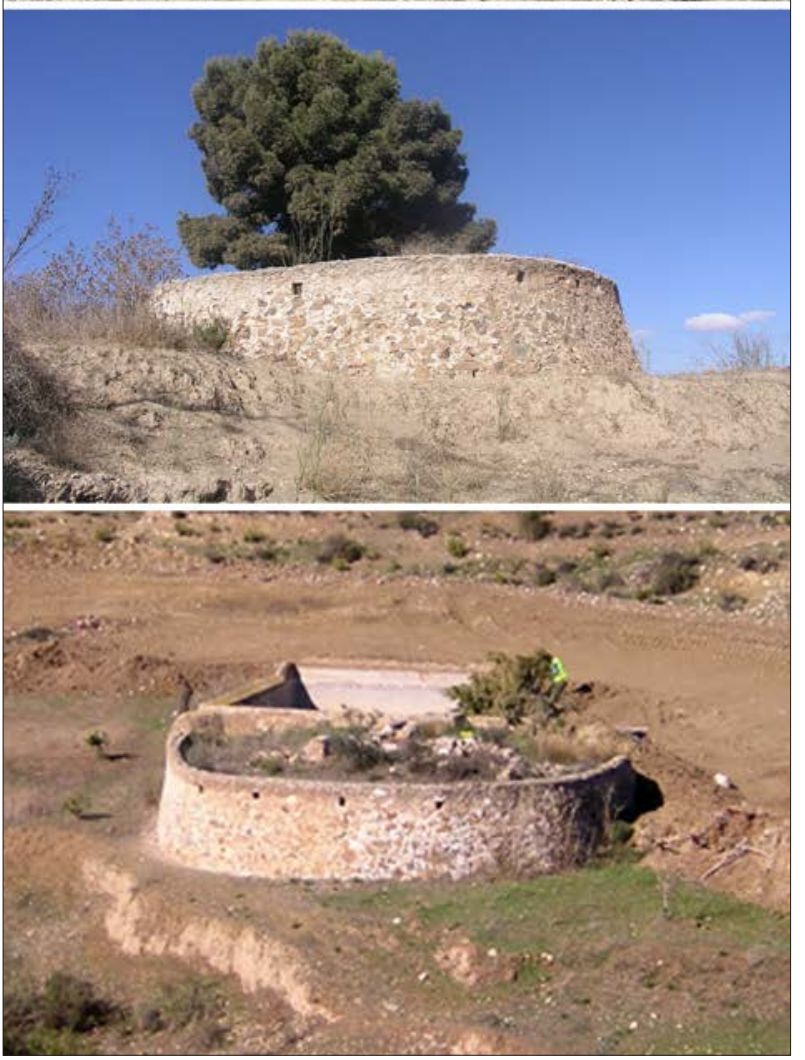

taner (1982) sobre las norias y aceñas de Murcia, una reproducción a escala real en el Museo Etnológico de la Huerta de Murcia en Alcantarilla (Lám. 5, 1-2; Fig. 7), dos fotografías recientes (Lám. 5, 3-4) y un vuelo aéreo de 1928 (Lám. 10) que nos ha permitido localizar alguna de ellas funcionando en aquel momento.

La "rueda" (vertical) o "noria" tiene un grueso eje cilíndrico ("mástil") del que parten cuatro o seis radios ("cruz"), que se insertan en la llanta de los canjilones (Lám. 5, 2). La cara externa de los canjilones está formada por tablillas rectangulares entre las que sobresalen los separadores radiales de los doce canjilones que lleva la noria. Por el exterior, cada canjilón tiene una abertura en forma de cuarto de círculo que facilita la toma de agua durante la inmersión y su expulsión a la canaleta de evacuación cuando llega arriba durante el giro. En la cara contraria (interna) se ensamblan los dientes ("punto") que engranan con la rueda horizontal. La "contrarrueda" está formada por dos aros que van ensamblados con "cruz" en el "mástil" vertical. A su vez los dos aros van unidos entre sí con veinte

Junto a este modelo genérico de aceña muy difundido por todas las regiones mediterráneas, hallamos en la huerta de Murcia otra clase de noria de tiro (en uso hasta hace algunas décadas) cuya peculiaridad fundamental radica en su fuente de alimentación: las acequias de riego; modelo heredero, sin duda, de las aceñas islámicas de Senda de Granada objeto de este trabajo (GARCíA y CERDÁ, 2007; GARCÍA BLÁNQUEZ, 2014).

Si bien no hemos podido constatar la conservación de ningún ejemplar, disponemos al respecto del inestimable estudio de E. Mon- barrotes verticales ("punto"), asegurados por fuera ("tarugo") con espigas de madera. Por encima de la contrarrueda, el "mástil" queda sujeto dentro de un grueso madero transversal ("ubio") anclado entre sendos pilares de fábrica. Este travesaño evita que el malacate (o "tiro") cause oscilaciones desequilibrando la transmisión. El "mástil" de la "contrarrueda" (formado generalmente por el tronco de un árbol, a penas desbastado), está ceñido en cada extremo por un aro de hierro ("ceño"). En su base se inserta una pieza cónica también de hierro ("borrón") que actúa como pivote de rotación sobre otra placa del mismo material 
(“caja del borrón”). El eje de la noria, por el contrario, aunque es una pieza elaborada por el carpintero, se encuentra igualmente rematado con "ceños" para reforzar en los extremos los respectivos borrones cilíndricos que rotan sobre durmientes de madera encajados en las paredes del pozo. Como decíamos, menos los puntos de fricción para los que se empleaba el hierro, el resto de la maquinaria está realizada con maderas que proceden de la huerta y su entorno cercano, empleándose en razón de su dureza y elasticidad, fundamentalmente, la morera, el albaricoquero y el olmo. Las más de doscientas piezas que componen la aceña ${ }^{38}$, se ensamblaban con técnicas sencillas de carpintería (machihembrado, cuñas, espigas, etc.) que permitían al propio campesino ajustar o reponer las piezas deterioradas.

La aceña de la huerta de Murcia (Fig. 8) como hemos visto se caracteriza, además, por la ausencia de la clásica cadena o rosario de arcaduces (inherente al tipo aceña más común y generalizado) y su sustitución por canjilones integrados en la propia rueda como en la noria clásica de corriente de agua (río o

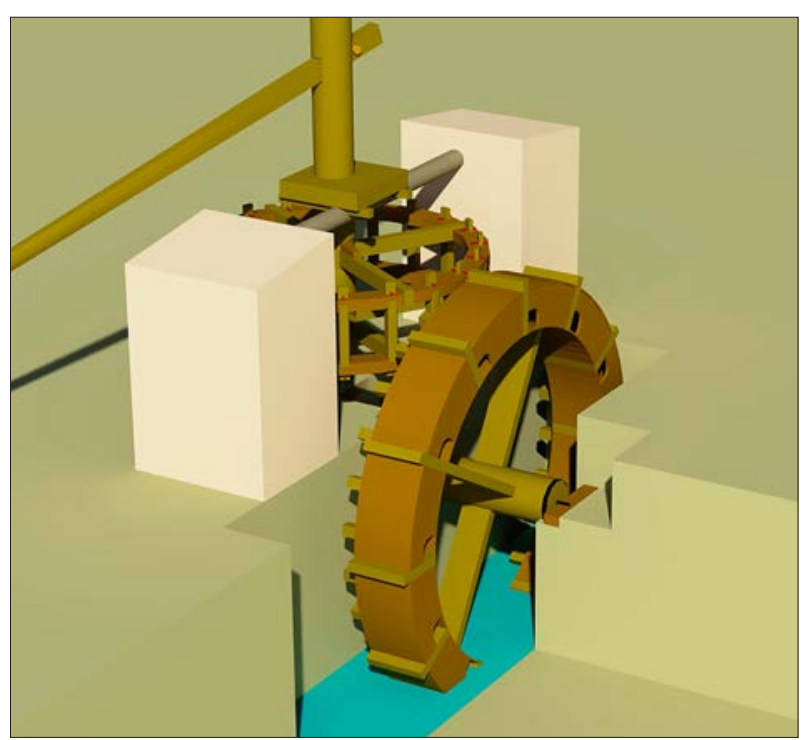

Figura 8. Dibujo de la reproducción a escala real de la aceña huertana expuesta en el Museo Etnológico de la Huerta de Murcia. canal) ${ }^{39}$. Esto hace necesario que el agua de su pozo no se encuentre más profunda que la parte inferior de la rueda hidráulica; caso que permitía incluso, dada la superficialidad del agua, remplazar la rueda de la noria por la de un ceñil, cuya rueda toma el agua por la cara externa de la llanta y la cede por el orificio situado junto al eje (Lám. 5, 3). Otra fotografía realizada por J. Torres Fontes (probablemente en la década de los setenta/ochenta del siglo XX) nos ofrece la imagen (Lám. 5, 4) de una aceña de acequia en su emplazamiento natural, junto a un canal de riego que, a juzgar por la amplitud de su cauce, debe corresponder al de una acequia Mayor.

\subsection{Las aceñas andalusíes}

En al-Andalus las aceñas debían ser relativamente numerosas (MANZANO MORENO, 1986: 623) tanto en el medio rural como en el urbano. Arqueológicamente se reconocen, fundamentalmente, por los restos de sus pozos aunque, a veces, el hallazgo de cierta cantidad de arcaduces permite vislumbrar, teóricamente, su proximidad. Sus pozos son rectangulares, estrechos y alargados, algunos de tendencia elíptica, pero siempre con los extremos redondeados, exceptuando algunos casos excepcionales que son rectos como la noria del Albercón de la Torre de las Damas (Generalife, Granada) (MALPICA CUELLO, 1991), de la Alcazaba de Almería (ORTIZ et al., 1993) o las aceñas 2 y 3 de Senda de Granada (Murcia). Por dentro suelen presentar un sencillo revestimiento de fábrica, generalmente un forro de mampostería ordinaria o, excepcionalmente, de ladrillo (caso del Albercón de la Torre de las Damas). En algunos casos donde la consistencia del terreno lo permite, la parte más profunda del pozo, puede quedar desnuda para facilitar el paso del agua (Les Jovades, Oliva, BAZZANA, 1987: 427, fig. 4).

38 GLICK, 1977: 644

39 Agradecemos sinceramente a don José Ignacio Pellicer Sánchez, responsable del Museo Etnológico de la Huerta de Murcia (Alcantarilla), su colaboración y los medios facilitados para estudiar y dibujar el modelo que exponen en los jardines del citado museo. 
En cuanto a sus dimensiones, apreciamos que los pozos de las aceñas rurales, con una media de 3,4 m, son más largos que los de ámbito urbano que no sobrepasa los 2,70 m, si bien en ambos casos, suelen tener una anchura similar que oscila entre 0,9 y 1,0 m, con la excepción del pozo del Albercón de la Torre de las Damas que alcanza un máximo de 1,3 m. El diámetro de las norias rurales superaría, pues, en algo menos de un metro a las urbanas que tendrían, por tanto, una capacidad extractiva mucho menor aunque suficiente, no obstante, para el tipo de abastecimiento que servía-doméstico, balnear o cultual-.

En al-Andalus la presencia de norias de tiro en las ciudades islámicas vinculadas al abastecimiento doméstico es un hecho constatado (JIMÉNEZ CASTILLO, 2013: 592, not. 1550). En madinat Mursiya se tiene noticia del hallazgo de ocho posibles aceñas: en los baños de San Nicolás (1) y del Trinquete (2), en el pequeño baño privado asociado al palacio Dâr as-
Sugrà (3), plaza de las Balsas (4), noria de la Catedral (5), Iglesia de San Juan de Dios (6), Jardín de San Esteban (7), Polo de Medina (8), de los cuales cuatro se conocen sólo por sus arcaduces (baños del Trinquete, San Juan de Dios, Jardín de San Esteban y Polo de Medina). El baño de San Nicolás conserva completo un pozo alargado de extremos redondeados, realizado en mampostería, (2,21 por 1,16 m) (Lám. $7,1)$. En el pequeño baño privado asociado al palacio Dâr as-Sugrà se documentó otro pozo ovalado de ladrillo (1'83 x 0'75 m) que se interpretó como pozo de aceña de rosario destinado a proporcionar agua al baño (POZO, 1999: 86-87, f. 5). En la plaza de las Balsas se localizó los restos de otro pozo similar, forrado con mampostería, en seco la parte profunda y con argamasa en el tramo superior, junto al que se ha conservado, de forma excepcional, el cimiento de uno de los apoyos de la rueda de tracción (ROBLES FERNÁNDEZ et al. 2002) (Lám. 7, 2-3). Se trata de uno de los pilares de ladrillo (0,6 m de lado) que soportaban el tra-


Lámina 7. 1. Pozo de aceña del Baño de San Nicolás (Murcia). 2. Pozo de aceña de Plaza Balsas (Murcia) con pilar de ladrillo adosado. 3. Detalle de la fábrica del interior del mismo pozo. 
vesaño ("ubio", en la terminología murciana) que sujeta el eje de la rueda de tracción ${ }^{40}$. La conservación de este elemento, que suele ser inusual (en el Albercón sólo queda las fosas de cimentación), nos permite confirmar que se trata realmente de una noria de tiro animal y no de tracción humana, como frecuentemente hubo de suceder en el medio urbano, debido a la escasez de espacio, como se constató en el baño de San Nicolás de Murcia (JIMÉNEZ CASTILLO, 2013: 644 y 668).

En Sark al-Andalus las aceñas rurales ligadas a la producción de regadío están atestiguadas desde el siglo VIII (GUTIÉRREZ LLORET, 1988 y 1996). Su rápida difusión hacia el resto de al-Andalus, entre los siglos IX y $X$, se ha podido rastrear gracias a los frecuentes hallazgos de arcaduces; las evidencias estructurales, por el contrario, son muy escasas. Los pozos de noria hallados en condiciones de estudio, además de los documentados en Senda de Granada, se reducen, tan solo, a cinco ejemplares ${ }^{41}$ : dos en Oliva (Valencia) (BAZZANA et al., 1987; BAZZANA, 1987: 421-432), el pozo del Albercón de la Torre de las Damas (Granada) (MALPICA CUELLO, 1991), el pozo de noria de la Alcazaba de Almería y otro en La Ollita, Niebla (Huelva) (BENABAT y PÉREZ, 1999). Los pozos del Albercón de las Damas, Alcazaba de Almería y las aceñas 2 y 3 de Senda de Granada (Murcia) son de planta rectangular regular; el resto presentan la forma clásica estrecha y alargada de extremos redondeados.

Los hallados en Les Jovades (Oliva, Valencia), de 2,8 de largo por 1,4 m de ancho y 3,3 por $1,15 \mathrm{~m}$, respectivamente, estaban construidos con mampostería. Este último, mejor conservado, tenía por dentro un sólido muro de piedra y argamasa de 0,65 $\mathrm{m}$ de espesor, que penetraba en el terreno hasta alcanzar una capa consistente de conglomerados a -3,26 $m$ de profundidad; el resto del pozo, hasta el estrato arcilloso impermeable (-6,85 m) carecía de revestimiento facilitando la entrada de agua alumbramiento a través de los estratos de gravas y arenas (Lám. 8, 1). La noria de La Ollita (Niebla) (Lám. 8, 2) no pudo ser excavada en profundidad debido a su precario estado de conservación. No obstante se reconoció, hasta un metro de profundidad un pozo de 3,10 de largo por 1,5 m de ancho (incluida la fábrica) construido igualmente con grandes mampuestos. En cuanto a su abastecimiento hídrico, la coincidencia del paso de un canal subterráneo junto al pozo lleva a los autores a interpretarlo como un sistema hidráulico combinado, con captación de agua procedente de un qanat y extracción mediante sâniya (BENABAT y PÉREZ, 1999: 242).

El pozo del Albercón de las Damas (Lám. 8, 3), creado en el primera mitad del s. XIV (MALPICA CUELLO, 1995: 414) resulta excepcional, si lo comparamos con la modestia de los ejemplos anteriores, por su planta rectangular y su construcción a base de ladrillo, peculiaridades que podrían estar ligadas al entorno de carácter palatino donde fue concebido. Se trata de un complejo sistema de abastecimiento hidráulico con fines agrícolas. El agua, procedente de una acequia, era conducida por un largo túnel excavado en la roca (provisto de arquetas de aireación) hasta el receptáculo del pozo, desde donde era elevada 25 m con una noria de tracción animal y trasvasada, por un canalillo, hasta la gran alberca que da nombre al complejo hidráulico (MALPICA CUELLO, 1995: 413-414).

40 La restitución que hacen los autores de la parte ausente del pozo nos parece insuficiente para albergar la rueda de tracción. Si consideramos que el eje de la rueda de tracción se encuentra entre los respectivos pilares, y que su corona se introduce en el pozo para engranar con la rueda vertical o del agua, su diámetro nos da la distancia mínima entre los machones y su centro el eje de simetría del pozo. De este modo la restitución que hemos realizado nos proporciona una longitud de 2,6/2,7 m, con una anchura de pozo (ya estimada en la planta original) de $0,9 \mathrm{~m}$.

41 El importante conjunto de norias de sangre (13) de origen andalusí de la alquería de Benassal (Castellón) no se ha tenido en cuenta dado que los restos documentados, incluidos sus pozos, como señala su autor, no se pudo verificar que "sean genuinamente andalusíes" (POVEDA SÁNCHEZ, 2004: 45). Otro tanto sucede con los cuatro supuestos pozo-cenia localizados en Torre La Sal, en los que no se ha podido concretar su identificación cierta, debido a su estado de conservación y a la ausencia de arcaduces, recipientes estrechamente vinculados a estas estructuras hidráulicas andalusíes (FLORS UREÑA, 2009: 220-225). 


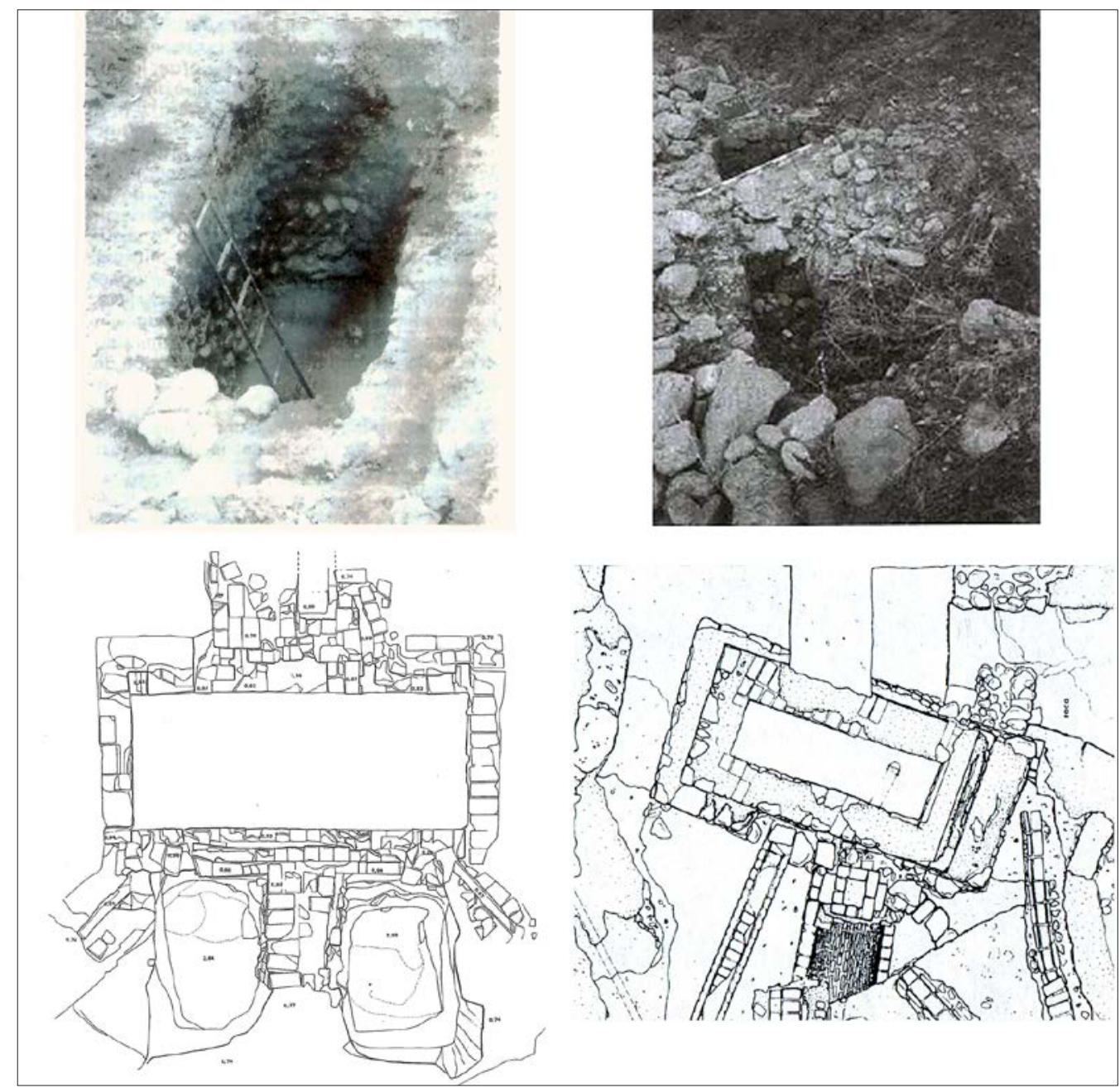

Lámina 8. 1. Aceña islámica de Les Jovades (Oliva, Valencia) (BAZZANA, 1987). 2. Aceña islámica de La Ollita (Niebla, Huelva) (BENABAT y PÉREZ, 1999). 3. Pozo de aceña del Albercón de las Damas (Granada) (MALPICA CUELLO, 1991). 4. Noria-aljibe del complejo hidráulico de la Alcazaba de Almería (ORTíz et al., 1993, fig. 5)

En la Alcazaba de Almería se halló un complejo hidráulico denominado noria-aljibe integrado por un pozo de noria rectangular construido con mampostería y $(2,40 \mathrm{~m}$ de largo por 0,74 de anchura, medidas internas) y un aljibe al que se hallaba conectado mediante una doble canalización: una para recargar la cisterna y otra que actuaba como rebosadero, encargada de conducir de nuevo las aguas sobrantes al pozo. Este complejo tuvo un uso continuado, con unos antecedentes romanos, y una mayor utilización entre los siglos X y XIII (ORTIZ et al. 1993, 106-107).

\subsection{El precedente alejandrino: el mode- lo de Kôm el-Dikka y sus recipientes cerámicos}

Aunque no es objeto de este trabajo analizar el origen y difusión de las máquinas hidráulicas de tracción animal o de su antecesora la rueda hidráulica extractora de agua ${ }^{42}$, no queremos dejar pasar esta oportunidad de referirnos a la máquina hidráulica documentada en Kôm el-Dikka (Alejandría, Egipto) (Lám. 9,1 ), artefacto que consideramos un precedente mecánico de la aceña árabe y, por tanto,

42 En esta ocasión no podemos extendernos en este interesante tema, por otra parte ya tratado por otros autores a los que remitimos, entre otros, para su estudio: COLIN, G. S. (1932), CARO BAROJA, J. (1954 y 1955), BOLENS, L. (1972), SCHIØLER, T. (1973), FORNEAS, J. M. (1974), MANZANO MORENO, E. (1986), GLICK, T. F. (1992). 
susceptible de análisis para determinar las diferencias técnicas entre un aparato y otro. No tenemos pruebas que permitan atribuir a los árabes estos avances tecnológicos, pero tampoco podemos asumir aquella opinión que sólo los considera meros difusores de un ingenio completamente desarrollado en época clásica.

Si bien se tiene constancia de que la rueda elevadora de agua proliferó por todo el Imperio Romano, no se puede afirmar lo mismo de la noria de tiro; las evidencias papirológicas (siglos III y II aC.), literarias (desde el siglo III aC.) y arqueológicas (a partir del siglo II aC.) señalan, por el contrario, Egipto como la zona de origen ${ }^{43}$ (OJEDA CALVO, 2006: 12-13), en concreto, Alejandría donde se encontró -en el monumento funerario de un agricultor hacia el siglo I o II dC. (Lám. 4: Museo Greco-Romano de Alejandría)- un estuco con la representación (más antigua) de la máquina hidráulica de tiro (o de sangre) que se difundirá en el occidente del Mediterráneo varios siglos más tarde de manos de los árabes.

Aunque el estudio de la mecánica de los engranajes se remonta al siglo III aC., fue precisamente en esta ciudad donde, de la mano de Herón (de Alejandría) (s. I dC.) la mecánica y la hidráulica obtuvo nuevos avances que favorecieron, quizás, su temprana aplicación práctica como ha puesto de relieve la arqueología. Podríamos considerar a Alejandría como el centro donde conocimiento teórico y aplicación práctica cristalizaron en la máquina hidráulica que conocemos como aceña o noria de tiro (o de sangre) en la que, más adelante, los cangilones cerámicos jugarán un papel crucial, desde el punto de vista arqueológico, al convertirse en indicadores materiales (fósil director) de una larga tradición tecnológica que se difundirá por toda la costa africana hasta el mediterráneo centro-occidental.

Concluiremos diciendo que la mecánica hidráulica aplicada a la aceña procede del Mediterráneo oriental, pero que fue la cultura árabe quien, tras su perfeccionamiento, la difundió en al-Andalus, si bien, mundo romano y musulmán tuvieron una misma fuente tecnológica de origen: los ingenieros helenísticos del siglo III aC. y sus herederos de la escuela de Alejandría (s. I dC.).

Aquel estuco, identificado también de E. Manzano (1986: 625), rememora una escena cotidiana de su vida y nos muestra una máquina compleja con una rueda vertical colocada en la boca de un pozo, unida mediante engranajes (no visibles) a un eje vertical con un doble travesaño al que van uncidos sendos búfalos de agua, que marchan sobre una plataforma elevada circular encintada con sillares ${ }^{44}$.

Aunque la calidad de la imagen que disponemos no es buena podemos observar, no obstante, detalles interesantes como la disposición de los elementos principales y sus proporciones. El tamaño de los búfalos (Lám. 9, 2) (y del probable personaje situado a la izquierda de la escena) nos permite realizar la modelización 3D de la máquina en su conjunto ${ }^{45} \mathrm{y}$, en consecuencia, proponer unas dimensiones aproximadas de aquel modelo (Lám. 9, 3). En el centro de la plataforma de unos $8 \mathrm{~m}$ de diámetro se sitúa la rueda $\varnothing$ $1,8 \mathrm{~m})$, de la que se representa aproximadamente un cuarto de la misma, dentro de un

43 Papiros grecorromanos del British Museum mencionan el empleo de máquinas de agua egipcias para el regadío y diversas aplicaciones industriales (R. OJEDA CALVO, 2006: 12-13)

44 Estuco romano encontrado en Alejandría en 1960, expuesto en la sala 15 del Museo Greco-Romano de Alejandría (http://www. grm.gov.eg/images/large/19.jpg). Su datación resulta muy problemática, estableciéndose un amplio margen que va del siglo I aC. a siglo I dC.

45 Para realizar la modelización 3D hemos tomado como medida base o de referencia la altura de la cruz del búfalo de agua (Bubalus bubalis) que es de $1,8 \mathrm{~m}$. Esta sería la distancia mínima, respecto del suelo, a la que se encontraría el travesaño horizontal (ensamblado al eje vertical) en el que iría el arnés de los animales de tiro. Una vez escalada la imagen con esta medida mediante software CAD, se ha corregido la fuga de la perspectiva en la que está realizado el dibujo. Con las medidas iniciales de referencia se ha dibujado todo el conjunto en planta y en alzado. Después, tomando como módulo el pie romano $(29,60 \mathrm{~cm})$ para recrear algunos elementos (fustes de madera, sillares, noria, etc.) se ha construido cada pieza en 3D, procediéndose luego a su ensamblaje para obtener en modelo en tres dimensiones y su posterior renderización. Dibujo y modelización 3D realizada por el autor. 

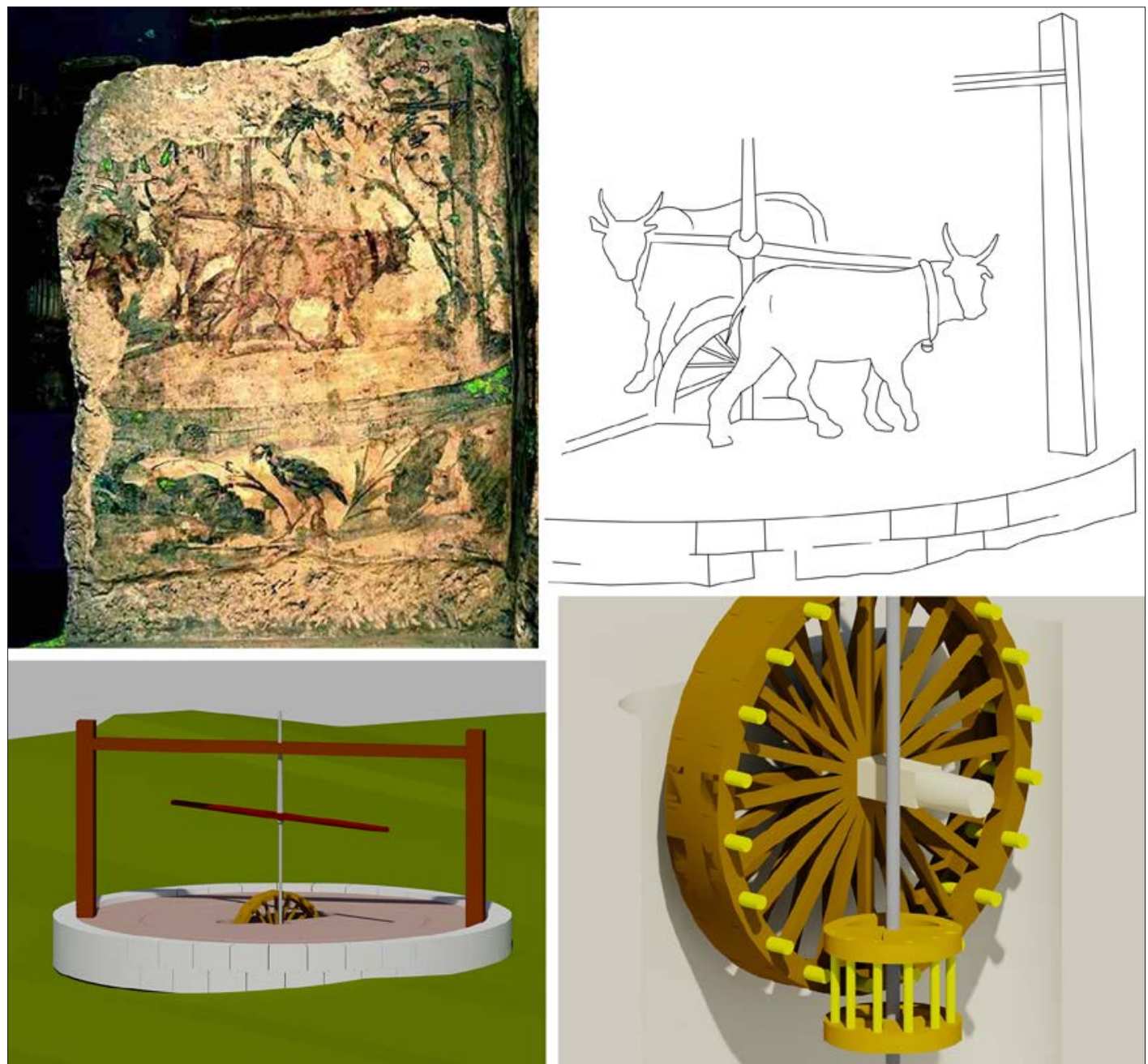

Lámina. 9. 1. Estuco funerario representando una rueda hidráulica de tracción animal sobre plataforma elevada circular (s. I aC.-I dC.). Museo Greco-Romano de Alejandría (Egipto), sala 15. 2. Dibujo lineal del estuco. 3. Modelización 3D de la imagen anterior. 4. Propuesta de engranaje en modelo 3D.

pozo estrecho y alargado (0,65 por 2,40 m). Se identifican cuatro radios más otro posible vertical detrás del eje motriz, por lo que dispondría de un máximo de 20 radios. La llanta externa es aparentemente plana y estrecha $(0,30 \mathrm{~m})$. Sobre ella, aunque la imagen carece de nitidez, podríamos reconocer la posible representación de algún recipiente, que vierte hacia un canalillo estrecho, casi alineado con la rueda, situado a su izquierda. Delante de la rueda se inserta verticalmente en el pozo el eje motriz, probablemente una pieza fabricada en hierro dada su delgadez, en la que se aprecia dos tramos: uno inferior de sección circular y otro, a partir del travesaño horizontal, de forma cónica. Este eje metálico debía apoyar, probablemente, en una pieza metálica capaz de soportar un gran peso y una fricción continua ${ }^{46}$. Por arriba el eje giraba dentro de una viga transversal horizontal, sostenida por dos fustes de madera de sección cuadrada $(0,30 \mathrm{~m})$, colocados diametralmente sobre el encintado de sillería perimetral. Finalmente un travesaño de madera horizontal (5,2 de longitud total) ensartado en el eje vertical, a cierta altura del suelo (por encima de la cruz

46 En la aceña huertana el eje de madera termina en una punta de hierro (borrón) y apoya en una placa del mismo material (caja del borrón). En los molinos de rodezno recientes estas piezas son de bronce y se llaman respectivamente punto y rangua (soporte de forma cúbica). Los ejes de la norias romanas documentadas en las minas Tharsis y Riotinto (Huelva) también son de bronce (OJEDA CALVO, 2006) 
del animal), servía para trasladar al eje de rotación vertical la fuerza motriz ejercida por sendos búfalos uncidos en sus extremos. El eje debía estar firmemente sujeto durante la rotación para mover con precisión una pequeña rueda horizontal (linterna o tympanum) (no visible) que engranaba con los dientes de la noria vertical47 (Lám. 9, 4).

El reducido diámetro de la noria, que esta se emplace sobre una plataforma elevada (no en un cauce) y la ausencia de orificios en el lateral de su corona, permiten suponer que para extraer el agua contaba con una cadena (o rosario) de cangilones de bronce o madera como describe Vitruvio en otras máquinas ${ }^{48}$. Sin embargo, sobre la llanta de la máquina de Alejandría, como decíamos, se vislumbra algún objeto que podríamos interpretar como la representación de un posible arcaduz, probablemente, cerámico. Sea acertado o no esta identificación, en esta misma ciudad de Alejandría M. Rodziewicz (1984: 259-278) documentó en el denominado "sector de las cisternas" (s. V), junto a cuerdas y ganchos, una gran concentración de fragmentos de gadous (arcaduz): "recipientes egipcios de función específica, para elevar el agua desde pozos y canales atados a cuerdas" (RODZIEWICZ, 1984: 266-267). Los gadous, como los llaman los egipcios actuales, son piezas de gran tamaño con cuerpo de tendencia apuntada con la parte superior globular o, bien, cilíndrico-globular, terminadas en un pequeño ápice basal biselado con botón central (Fig. 9, 1-2), cuya semejanza con algunos arcaduces andalusíes de Tudmir y sicilianos es evidente (GARCÍA BLÁNQUEZ, 2014).

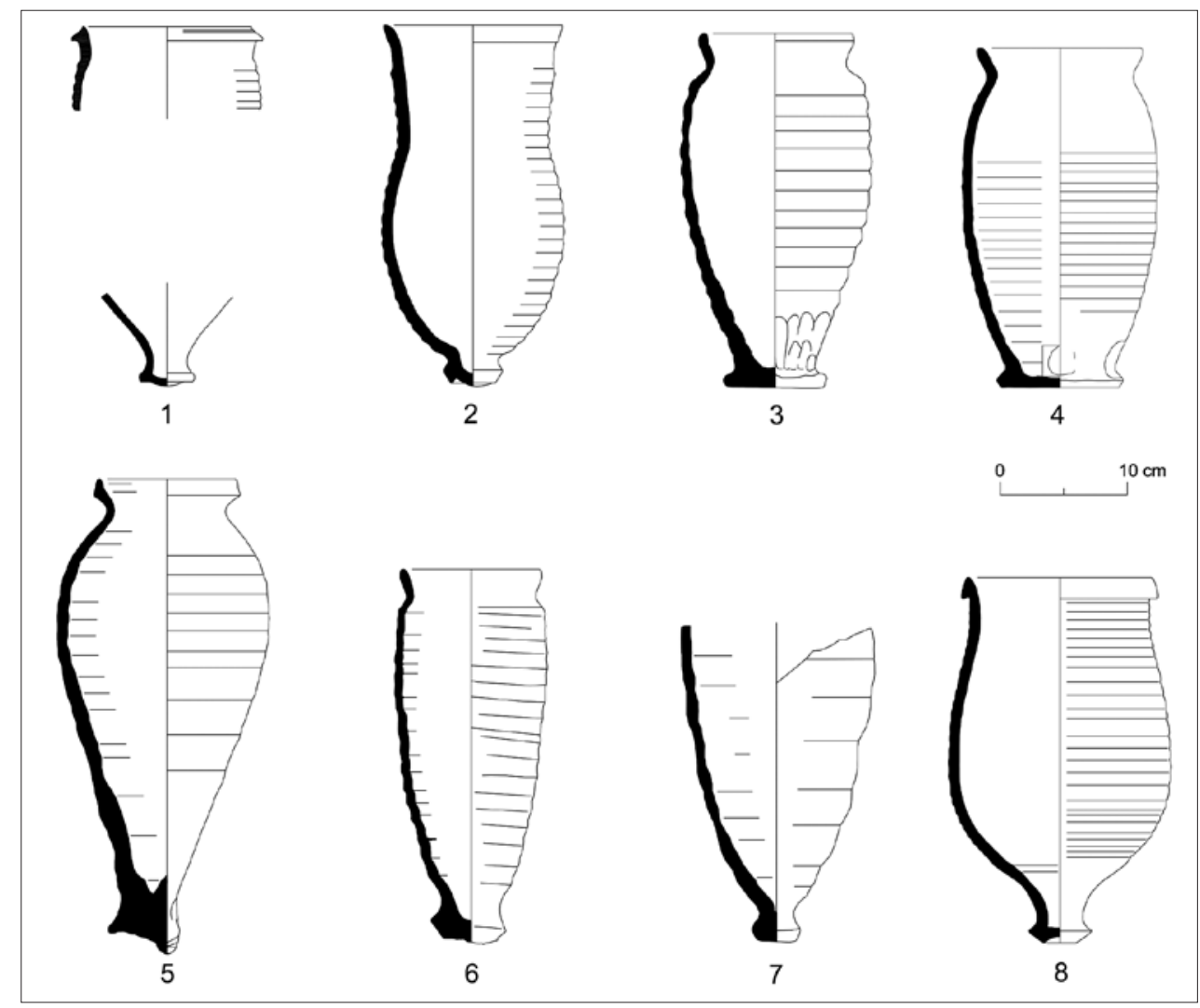

Figura 9. Arcaduces de amarre próximo-distal mediterráneos: 1 y 2, Kôm el-Dikka (Alejandría); 3, Rojales (Alicante); 4, Lorca (Murcia); 5, Senda de Granada (Murcia); 6, Murcia; 7 , Guardamar (Alicante); 8, Palermo (Sicilia).

\footnotetext{
47 Aunque esta parte queda oculta en la representación, es evidente que el eje de rotación vertical movido por tracción animal ha de hacer girar a la rueda vertical gracias a un engranaje sencillo dispuesto horizontalmente, tipo linterna (tympanum). Aparentemente esta rueda horizontal debía ser de reducidas dimensiones, pues en el suelo no se aprecia ningún hueco grande.

48 (De Architectura, X, 4-1-3, 51)
} 
Desde el punto de vista cronológico los hallazgos de Kôm el-Dikka (Alejandría) -la primera representación de una rueda hidráulica de tiro (s. I aC.-I dC.) y los cangilones del "sector de las cisternas" (s. V dC.)-, constituyen, sin duda, los precedentes de las máquinas hidráulicas de tracción animal que más tarde reencontraremos bajo otra apariencia en el otro extremo del mediterráneo, en Sark alAndalus.

Desde el punto de vista tecnológico hemos de señalar que ambas máquinas, la noria (de tiro) alejandrina y la aceña árabe andalusí trabajan bajo un mismo principio mecánico: la doble rueda engranada en ángulo recto. Sin embargo la aceña andalusí incorpora una serie de avances técnicos respecto de la alejandrina que mejoran no solo su rendimiento mecánico sino que además, en la práctica, reducían su coste de construcción y ayudaban a su mantenimiento. La noria se hace más robusta y aumenta de diámetro como recomienda Ibn al-Awwān, para aprovechar la inercia de su masa. La rueda horizontal, en la máquina alejandrina de pequeño tamaño (linterna) y empotrada en el pozo, se desplaza fuera y aumenta también de tamaño consiguiendo en su rotación, ahora con un único brazo de tracción, multiplicar el número de vueltas de la rueda vertical (noria). Y la gran superestructura de madera para sujetar el eje vertical, se transforma en dos pequeños pilares de fábrica con un simple travesaño. Las mejoras técnicas, la sustitución de algunos materiales por otros más accesibles y baratos y los nuevos métodos de construcción permiten al propio campesino, con ayuda de algún artesano, fabricar la máquina, realizar ajustes y llevar a cabo las reparaciones el mismo.

Las aceñas que hoy día encontramos por todo el mediterráneo occidental difieren sustancialmente del modelo alejandrino. Aquel sencillo principio mecánico inicial fue perfeccionándose, no obstante, a lo largo de varios siglos, probablemente en Oriente Medio, hasta alcanzar el desarrollo técnico que conocemos cuando los árabes las llevan consigo a Occidente (hacia finales del siglo VIII). A juzgar por los artefactos actuales, es evidente que hubieron diversas vías evolutivas que dieron lugar al desarrollo de varios modelos técnicos con características regionales diferenciadoras que, a día de hoy, están representados por la aceña Egipcia de tres ruedas engranadas y la aceña Siria de dos ruedas con pilares de fábrica, modelo éste que constituye el paralelo reciente más próximo de la aceña de tipo andalusí que encontramos actualmente en la península Ibérica, el Magreb o las islas Baleares.

\section{LAS ACEÑAS DE ACEQUIA DE SENDA DE GRANADA: INTERPRETACIÓN FUNCIONAL Y EVOLUCIÓN HISTÓRICA}

Las aceñas de Senda de Granada presentan ciertas peculiaridades exclusivas y diferenciadoras como su fuente de abastecimiento desde una acequia, la presencia de un conducto subterráneo en el pozo o la escasa profundidad de éste, que las alejan radicalmente de los modelos recientes que acabamos de describir y de los modelos clásicos islámicos que se conocen. Aunque carecemos de cualquier evidencia que no sea el pozo, podemos, no obstante, intentar una reconstrucción preliminar de la maquinaria y su funcionamiento, tomando como modelo los restos de la aceña 2 y la toma de la 4 (Fig. 10-1).

En este caso el pozo, con una longitud de 3,48 m, debía albergar una rueda vertical o del agua ("noria"49) de unos $3 \mathrm{~m}$ de diámetro, alcanzando 3,23 m con los arcaduces. Teniendo en cuenta que no debía soportar el peso de las norias que portan la cadena de arcaduces, consideramos que la rueda, construida íntegramente en madera, tendría una estructura sencilla y más liviana. Estaría formada por un eje central ("mástil") del que

49 En la descripción teórica de la aceña de acequia islámica de Senda de Granada, emplearemos la terminología de M. E. Montaner (1982) expresada en el croquis de la aceña huertana (Fig. 17). 

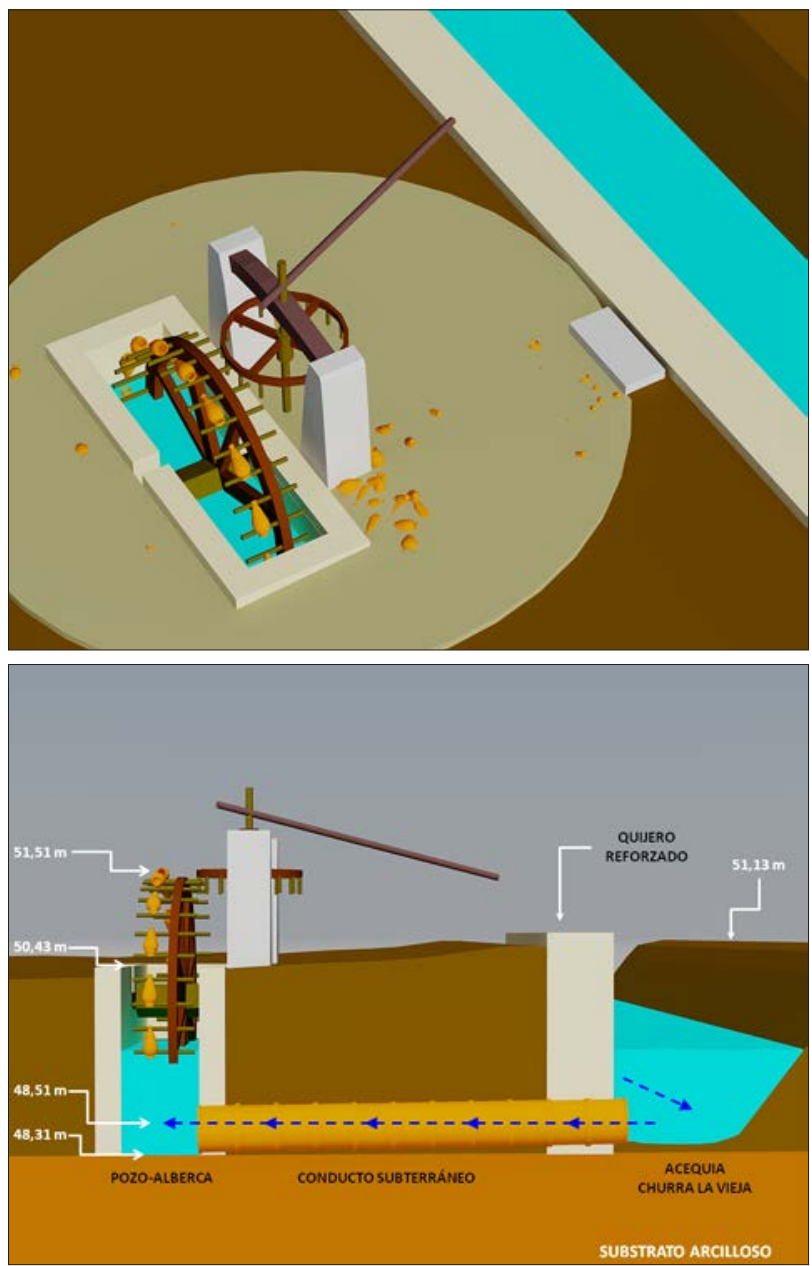

Figura 10. Sección transversal de la modelización 3D teórico de la aceña 2 de Senda de Granada (Murcia), con representación de la maquinaria y la acequia.

partirían los ejes radiales (“cruz”) hacia un aro perimetral simple, en el cual se insertarían los dientes del engranaje ("punto") por un lado y los vástagos donde irían atados los arcaduces, por el otro. Considerando para los arcaduces una altura media de $37 \mathrm{~cm}$, sería posible colocar en la rueda hasta un máximo de 16 recipientes dejando entre ellos una distancia mínima de $20 \mathrm{~cm}$, de lo que se deduce un total de 32 apoyos y, por ende, de dientes para engranar con la rueda de tracción o del aire ("contrarrueda"). Esta rueda dispuesta horizontalmente rotaría entorno de un eje de madera sujeto por un grueso travesaño ("ubio") colocado, probablemente, entre sendos pilares de fábrica ${ }^{50}$. Un animal uncido a una larga pértiga ("tiro") haría girar el eje de la rueda del aire poniendo en marcha el mecanismo de extracción. Este eje podría terminar en una punta metálica (como las aceñas recientes de la huerta de Murcia) o ser totalmente de madera como los casos documentados por $\mathrm{T}$. Schiöler en Jartum (Sudán). En este caso la fricción entre sí del eje y el durmiente ocasionaría un desgaste tan acusado que obligaba a cambiarlo de posición cada cierto tiempo ${ }^{51}$. El "mástil" de la noria (vertical) apoyado sobre cojinetes de madera se encastraría en el terreno a nivel superficial o bien a una profundidad máxima equivalente a un cuarto de su diámetro, de modo que parte de la rueda con los arcaduces quedaran sumergidos en el agua acumulada en el fondo del pozo procedente de la acequia.

Hasta aquí, todos los elementos que acabamos de describir se encuentran en las aceñas comunes cuyo caudal mayoritariamente procede de un acuífero profundo o, a lo sumo, de un canal subterráneo ${ }^{52}$. Sin embargo, las

50 Aunque en Seda de Granada no conservamos evidencias de estos pilares, sabemos por los restos conservados en la plaza de las Balsas de Murcia y las respectivas fosas de cimentación del pozo del Albercón de las Damas (Granada) que la rueda de tracción se sujetaba con estas estructuras de ladrillo. No obstante, el eje vertical quedaba estabilizado entre grandes puntales de madera hincados en el suelo.

51 http://www.kattler.dk/schiolers/uk/detaljer.html. Fotografía 125: Debido a la fricción (madera contra madera) y el peso de la rueda, la aceña emite un ruido chirriante que se puede escuchar a gran distancia y le dice al campesino si la sâqiya está regando o no su campo.

52 M. Bertrand y P. Cressier documentaron en el espacio agrícola de Rágol, en el valle del río Ándarax (Almería), un microsistema de irrigación hispano-musulmán con una acequia, subterránea en algunos tramos, en el que se instalaron, ya en época cristiana (1986: 69), tres aceñas que extraían el agua de uno de estos tramos subterráneos (- 10 m) para regar parcelas situadas en una cota superior a la del cauce (1986: 65). En el caso de La Ollita los excavadores consideran que se trata de un sistema hidráulico combinado en el cual la aceña obtenía el agua de un qanat que, probablemente, circula junto al pozo (BENABAT y PÉREZ, 1999: 242). La aceña del Albercón de las Damas emplea un sistema de abastecimiento más sofisticado y costoso: recibe agua de una acequia distante a través de una galería excavada en la roca provista de pozos-respiradero de control (MALPICA CUELLO, 1995: 413). 
aceñas de Senda de Granada poseen un sistema de captación hídrica diferente, pues, en nuestro caso el agua sale de una acequia a cielo abierto y no de un pozo o galería de alumbramiento (Fig. 10-2). La orientación de los conductos cerámicos subterráneos, su posición en el fondo del pozo y la pendiente constatada, hace prever que las cañerías conectarían con las respectivas acequias, cuyo lecho circula a unos metros de distancia. De este modo, el agua entraría por el fondo en esta especie de pozo-alberca elevándose su nivel, por la ley de vasos comunicantes, hasta alcanzar la misma cota que la acequia. Cargado el depósito se podía iniciar la extracción, creándose un flujo de entrada y salida continuo. El agua trasvasada servía para regar terrenos situados a una altura ligeramente superior que la acequia ${ }^{53}$. Cuando cesaba la extracción el flujo se detenía por si sólo sin peligro de pérdida o perjuicio para otros regantes. En la acequia la toma tendría un aspecto similar al documentado en la aceña 4 , donde el quijero de tierra fue remplazado por un paño de hormigón encofrado, en el que se inserta la cañería de cerámica, reforzada con mampuestos y argamasa justo en la base de lecho ${ }^{54}$. En principio, no nos consta que tuviera ningún mecanismo de control o restricción del paso del agua aunque, después, sabemos por las Ordenanzas y Costumbres de la Huerta de Murcia (1889) que debían contar con un portillo en la acequia (Art. 158, 1a) ${ }^{55}$. Dispositivo que este estaba más relacionado quizás con el régimen de riego de cada acequia (de toma "abierta" o "cerrada") - "Solamente podrán utilizarse del artefacto en las horas de riego que correspondan al dueño de la ceña por el número de tahúllas que tuviere con riego de aquel cauce" (Art. 158. 3a)- que con el propio sistema hidráulico, pues las aceñas "no se las consideraba de otra manera que como un medio de que se valía el regante para sacar su agua del cauce, sin que su empleo o el de otro medio cualquiera modificara en lo más mínimo su derecho en cantidad ni en calidad" (DÍAZ CASSOU, 1889: 123).

Respecto de los prototipos islámicos, las aceñas de Senda de Granada presentan además otros aspectos novedosos como el tipo de fábrica empleado en la construcción del pozo o la forma singular de su planta. Llama la atención el excepcional uso del encofrado de hormigón (aceña 2, 3 y 4) frente a la casi unánime fábrica de mampostería ordinaria (con o sin mortero) que emplean el resto de las aceñas islámicas rurales. Los pozos de aquí presentan una fábrica más propia de una alberca que de una aceña, porque tratan de evitar la filtración del agua trasvasada, al contrario que los pozos desnudos o la mampostería ordinaria que favorecen la permeabilidad y penetración de agua en el receptáculo. Además, el intento por alcanzar mayor eficacia de almacenaje hizo desechar no solo la fábrica de mampostería sino también el tipo planta estándar de extremos redondeados, quizás menos apropiado para acopiar agua, que el cierre angular de las albercas y aljibes comunes.

No obstante, no deja de llamar la atención que en un sistema islámico de regadío, donde la circulación de caudales y su reparto en la parcelas de cultivo se rige por la ley de la gravedad, el trasvase de agua desde la acequia no se hiciera a través de un sencillo portillo y se recurra a un sistema de extracción tan complejo. Según J. Torres Fontes cuando las tierras

\footnotetext{
53 En los espacios irrigados mediante aceña de manto freático, se considera que el tamaño de la noria cercana a los 4 metros de diámetro permite prescindir de la construcción de la habitual balsa de almacenaje, como sucede en La Bolicha o incluso sólo 3 m en Casal dels Moros o La Cassasa, ambos localizados en el conjunto hidráulico de Benassal (POVEDA SÁNCHEZ, 2004: 50 y 53). En nuestro caso el sistema hidráulico carece de albercas o balsas independientes donde acopiar grandes cantidades de agua para regar posteriormente. El propio caudal de las acequias y una capacidad extractiva suficiente con ruedas que superan los 3 m de diámetro en las aceñas 2 y 3 , también harían innecesario construir grandes albercas.

54 Consideramos que las estructuras conservadas en las aceñas 1, 2 (conducto y pozo) y 4 (toma y conducto) son elementos estructurales complementarios. La conjunción de todos estos elementos da, pues, sentido estructural y funcionalmente al ingenio hidráulico que denominamos aceña de acequia.

55 Capítulo decimoquinto. "De la Ceñas. Art. 158 (...) 1 1a El portillo del cauce por donde toman el agua se ha de construir de piedra
} o ladrillo y solera de piedra. (...)". Ordenanzas y Costumbres de la Huerta de Murcia (1989). 
estaban a mayor altura que los cauces de distribución se empleaban la rafa ${ }^{56}$ y cuando era mucha la diferencia se usaban "artilugios de diversas clases"57 (aceña, algaidón, etc.) aunque también añade que estos "artilugios" se encontraban sistemáticamente en tierra de secano (albar) ${ }^{58}$.

Sin embargo, las açenias en la huerta andalusí murciana no debían ser excepcionales; su hallazgo en Senda de Granada pone de manifiesto que éstas se emplazaban también en zonas de huerta con regadío plenamente consolidado, aunque esta condición en época cristiana minoraba el valor de la tierra. En este sentido el mismo autor cita un caso parecido en la acequia Albadel (heredamiento de mediodía): una "açenia que tira agua de la açequia", donde al cifrarse la suma de tahúllas que tenía su propietario se especifica que "son las III en riego de açenna" para distinguirlas de las tahúllas restantes ${ }^{59}$.

Aquella forma de extraer agua de las acequias no debió ser algo inusual sino generalizado y extendido en ambos heredamientos. En época cristiana las fuentes confirman su continuidad, en el siglo XVIII la cartografía nos muestra su vigencia y la fotografía aérea reciente $(1928,1956)$ ofrecen ejemplos de su pervivencia hasta hace unas décadas. Los mapas históricos representan aceñas en el río Segura junto al Azud Mayor (1739) (Fig. 11) y en la acequia de Beniaján (1780) (Fig. 12), mostrándonos cómo la toma de agua se realizaba en estos casos mediante un canal a cielo abierto ${ }^{60}$. Sin embargo, la vista aérea de la acequia mayor de Barreras o Alquibla (Lám.



Figura11. Detalle del Plan Geométrico del Azud Mayor de la Ciudad de Murcia y sus confines situado en el Río de Segura;Hecho en el Año de 1739 (1789). (Archivo de la Confederación Hidrográfica del Segura, Murcia).

56 La rafa es una técnica de riego consistente en el que represamiento temporal del agua en el canal de riego para elevar el caudal circulante hasta la altura de la toma de riego, situada siempre a una cota superior.

57 TORRES FONTES 1990, 35.

58 Ídem, 39. Cuando la tierra de albar tenía esta clase de riego (de aceña), el valor en alfabas que se atribuía a la tahúlla (de albar) se incrementaba respecto de la que no lo tenía.

59 ldem, 38.

60 Siempre se ha admitido la presencia de la aceña o noria de sangre en la huerta de Murcia, aunque su uso se relegaba espacialmente a la periferia del sistema de irrigación, donde se empleaba de forma abusiva e ilícita para ampliar el área regable por encima de la línea de rigidez. Sin embargo, este no es el caso de las aceñas que tratamos integradas en la red de acequias islámicas. 

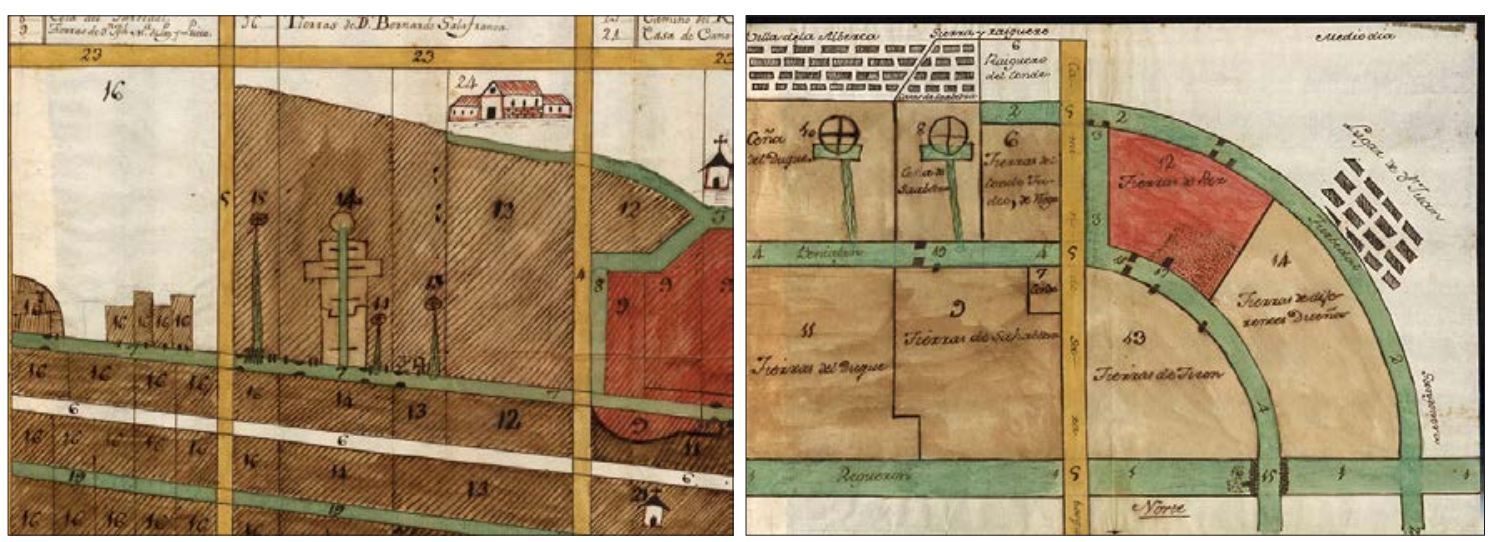

Figura 12. Plan de las Acequias Turbedal y Beniaján (cauce viejo de la misma), Alquibla, Alquibleta y Reguerón. Delineado e iluminado por mano de Don José María de Paz y Prieto. Año de 1780.

9), cerca de la población de Javalí Nuevo61 y la aceña fotografiada por J. Torres Fontes (Lám. $5,4)$ ofrecen, por el contrario, ejemplos de tomas semejantes al empleado en Senda de Granada, en los que la fuente de abastecimiento es la acequia y la única forma de captación posible ha de ser por conducto subterráneo. Podríamos deducir, pues, que el modelo de aceña con toma subterránea se puede considerar de tradición islámica, en tanto que la de canal abierto (de construcción y conservación más sencilla) sería cristiano o posterior62.

El sistema aunque complejo, en definitiva, debía resultar eficaz, especialmente en aquellos puntos donde no se podía regar por gravedad, es decir, cuando el lecho de la acequia se encontraba ligeramente más bajo que los terrenos de cultivo adyacentes. Las reiteradas inundaciones de la huerta, además de los efectos destructivos de las riadas, causaban la elevación progresiva no solo de las parcelas de cultivo por acumulación de limos (entarquinamiento) sino del propio cauce del río en la llanura aluvial (LILLO CARPIO, 1989: 1688), fenómeno morfogenético que no pasó desapercibido a los autores árabes que lo describen a finales del siglo XII: "(...) Murcia saca más ventaja en el aprovechamiento, para el riego, de las aguas de su río, puesto que, a diferencia de lo que sucede en Sevilla, el río de Murcia cabalga sobre su tierra, mientras que es Sevilla quien monta a su río (...)" (CARMONAy POCKLINGTON, 2008: 59)63. Quizás fuera este proceso de avenidas periódicas que adolece la vega de Murcia (hecho desconocido en otras huertas andalusíes) el que consolidó su empleo secular, sin descartar, tampoco, otros motivos que aconsejaran su aplicación como el de facilitar la permanente disposición de agua independientemente del nivel del caudal circulante, sobre todo en los períodos de estiaje veraniego.

De los dos modelos de aceña constatados en Senda de Granada, el más antiguo (aceñas 1 y 3) presenta estructura alargada, de tendencia rectangular, con los extremos menores curvos. Muestra una fábrica peculiar de mampostería, tomada con argamasa, con hiladas de piedra colocada en espiga. En el extremo de uno de sus lados mayores parte una cañería subterránea construida con tubos de cerámica. Este conducto se orienta hacia el lecho de la acequia, donde se halla la toma de agua propiamente dicha. Las aceñas más recientes (2, 3 y 4), a diferencia de las anteriores, están construidas con hormigón

61 Vuelo histórico de Ruiz de Alda (1928), fotograma B-105-25. En esta imagen se puede apreciar como los ingenios hidráulicos se sitúan indistintamente a un lado y a otro del cauce de la acequia Mayor de Alquibla, caso que también pudo suceder en el cauce islámico de Churra la Vieja en Senda de Granada.

62 Mientras que la aceña islámica sólo se emplea para extraer agua de la acequia, las aceñas dibujadas en la cartografía histórica pretenden además, mediante larguísimos canales, ampliar la superficie regable de espacios situados a mayor altura.

63 Texto de 'Abdallāh al-Hiğārī que cita Ibn Sa'īd al-Magribī en su Mugrib fī hulà l-Magrib, en el que compara los ríos de las ciudades hermanas de Sevilla y Murcia. 
encofrado y son de planta rectangular con los extremos rectos (2 y 3). Igual que la aceña antigua dispone también de un conducto subterráneo de atanores cerámicos que penetra hasta la misma base del canal, a través de un muro encofrado de refuerzo.

Aunque desconocemos las razones ciertas por lo que estas estructuras fueron amortizadas intencionadamente en época islámica (aceñas 1,2 y 3), sabemos por las fuentes cristianas que su empleo no cesó con la migración árabe tras la revuelta mudéjar (1264). El Repartimiento de la Huerta de Murcia (último cuarto del s. XIII) menciona aceñas en Albadel (TORRES FONTES, 1990) (heredamiento de mediodía), mientras que algunas ordenanzas del siglo XIV hablan de la existencia de arcaduçes en otros lugares del heredamiento norte como Beniscornia, Algualejas o los huertos de la Arrixaca (ROBLES FERNÁNDEZ, 2006: 11). A principios del siglo XVIII, el concejo de Murcia recibía numerosas solicitudes para instalar nuevas aceñas en las acequias, justificadas todas ellas por la imposibilidad de regar debido al recrecimiento de los terrenos (MONTANER SALAS, 1982: 48-51). La cartografía histórica de esta época (s. XVIII) nos ofrece la representación gráfica de aquellos ingenios con la innovación que mencionábamos: la

Lámina 10. Tramo inicial de la acequia mayor de

Barreras, junto al azud Mayor de la Contraparada, en el que se aprecian tres aceñas de acequia. Fotograma B-105-25 del vuelo de Ruiz de Alda (1928). transformación del conducto subterráneo en un canal construido a cielo abierto ${ }^{64}$. A pesar de todo, la continuidad del modelo islámico ha quedado constatada en pleno siglo XX por la fotografía aérea reciente (Lám. 10) ${ }^{65}$.

La datación de estos conjuntos estructurales, en razón de las relaciones estratigráficas y del registro cerámico se ha visto respaldada, a su vez, por la identificación cronológica de sus fábricas, para lo que nos apoyamos en un estudio reciente centrado en las técnicas constructivas del medio urbano de la Murcia andalusí (NAVARRO y JIMÉNEZ, 2011). La evolución entre un modelo y otro se ha determinado primero en razón de la sustitución de la aceña 1 por la 2, de mayor tamaño y capacidad hídrica, y la ausencia absoluta en este conjunto de arcaduces de amarre próximo-medial (tipo II de Senda de Granada), que se datan a partir del siglo XII. Por otra parte, en la estructura de la aceña 3, donde se conservan tramos de ambos tipos de fábrica, se constata como la fábrica de mampostería en espiga recibe la de hormigón (más reciente), al tiempo que en el interior de su pozo-alberca no se documentan

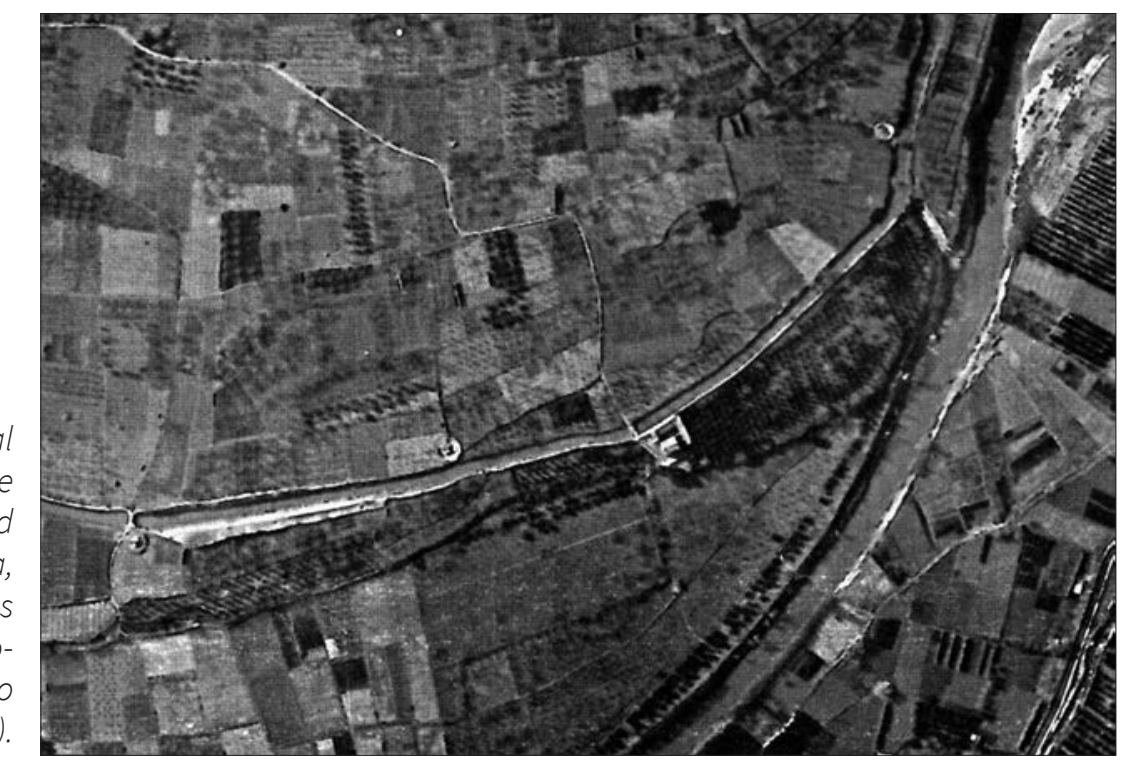

64 Mejora técnica que parece estar motivada por la gran distancia existente entre la fuente de abastecimiento (la acequia) y el punto de extracción del agua (la aceña). Este alejamiento progresivo tenía como finalidad incrementar la superficie regable más allá de la línea de rigidez, práctica muy extendida en época reciente (s. XIX), sobre todo, en el heredamiento de mediodía.

65 En la restitución cartográfica de los vuelos históricos de 1927/28, ha sido posible identificar numerosas aceñas de tipo islámico con conducto subterráneo. Este hallazgo nos ha permitido abrir una nueva línea de investigación centrada en la prospección selectiva de los espacios que ocupaban aquellas estructuras hidráulicas, hoy mayoritariamente desmanteladas, para verificar su conservación y registro material cerámico. La investigación de laboratorio ha sido posible gracias al portal IDERM (Infraestructura de Datos Espaciales de la Región de Murcia): http://iderm.imida.es/cartomur/ 
arcaduces de amarre próximo-distal (tipo I de Senda de Granada), modelo que fue remplazado a finales del siglo XI o principios del XII, mientras que fuera si se registran algunos extremos distales engrosados del modelo antiguo tipo I (ss. X-XI). Finalmente, en la toma de la aceña 4, donde la fábrica de mampostería en espiga está ausente, los fragmentos que se registran son exclusivamente de escotadura central, del modelo más reciente en Murcia, hecho que implica una datación a partir del siglo XII (GARCÍA BLÁNQUEZ, 2014).

En definitiva, podríamos considerar que las aceñas conservadas en Senda de Granada constituyen, si no un nuevo modelo, si una aplicación novedosa y desconocida arqueológicamente en los macro-sistemas de irrigación andalusíes. Su peculiar estructura y desarrollo funcional ligado a una acequia, caracterizan a este singular ingenio hidráulico que hemos denominado, en razón de su fuente de abastecimiento, aceña de acequia. La concentración constatada en este sector del heredamiento norte en época islámica, las posteriores referencias a ellas en el Repartimiento de la Huerta de Murcia, y su pervivencia material hasta hace pocos años, reclaman su ingreso en la nómina de elementos que integraban la huerta andalusí, no solo en su paisaje sino también, quizás, en aquel registro sonoro que también refieren los poetas árabes: la melodía quejumbrosa que emitía la noria, ahora, tal vez, acompañada del chirrido de la aceña que, desde la lejanía, anunciaba al campesino que sus campos se estaban regando (SCHIÖLER, 2012).

\section{SENDA DE GRANADA EN EL SISTEMA DE IRRIGACIÓN MURCIANO. CONCLUSIÓN}

A lo largo de este trabajo hemos tenido oportunidad de comprobar el origen andalusí del sistema de riego documentado en Senda de Granada. La secuencia estratigráfica registrada en sus tres cauces permite descartar, como anunciábamos, un origen preárabe y afirmar su construcción en época medieval islámica66: la acequia Alfatego discurre sobre los niveles tardoantiguos previamente amortizados, el quijero meridional de Churra la Vieja se superpone al nivel de sepulturas de la Necrópolis Norte (sector C1 de la excavación) y en el antiguo tramo de Alfatego (acequia del Tablacho) ocurre otro tanto, cuando su cauce cruza sobre una instalación productiva romana ${ }^{67}$. La datación relativa que ofrece la secuencia estratigráfica se ha visto confirmada, a su vez, por la indudable filiación islámica de las aceñas y de los recipientes cerámicos asociados a sus respectivos pozos.

Respecto de la creación o formación del sistema hidráulico andalusí murciano se ha de considerar, pues, como un proceso progresivo para el que, hoy por hoy, no ha sido posible determinar su evolución más que a grandes rasgos (Fig. 13). Se acepta de forma generalizada que las respectivas acequias madre (Aljufía y Alquibla) fueron los cauces primigenios a partir de los cuales se desarrolló el resto del sistema, siendo éstos, por tanto, los canales de mayor antigüedad (POCKLINGTON, 1990: 159). Mediante este proceso, una vez construida la acequia mayor de cada heredamiento el espacio irrigado fue ramificándose paulatinamente de modo que las zonas periféricas del sistema, situadas a mayor altura, se consideran más recientes que las interiores, más próximas al río (teoría de la ramificación de la acequia mayor de Aljufía). Según esto el heredamiento norte alcanzaría su máxima extensión cuando se abrió Churra la Vieja, supuestamente en un momento avanzado del período andalusí (ss. XII-XIII), dado que su trazado discurre por la cota más alta y alejada del heredamiento, solo superada ya en el siglo XVI con la creación de Churra la Nueva, una nueva acequia mayor

\footnotetext{
66 Algunos autores apuntan un posible origen romano aduciendo cierta geometría del parcelario de la huerta de Murcia (Rosselló y Cano, 1974) o la existencia de estructuras hidráulicas antiguas, tipo qanat, a las que se atribuye un origen pre árabe; no obstante, esta opinión está aún por demostrar y los resultados estratigráficos de Senda de Granada lo contradicen.

67 En el heredamiento de mediodía conocemos un caso parecido localizado bajo el espacio que ocupa las instalaciones nuevas del Museo Etnológico de la Huerta de Murcia entre la acequia mayor de Barreras (Alquibla) y la de Turbedal, donde en el curso de su edificación se hallaron diversas construcciones romanas por debajo del nivel de ambas acequias.
} 


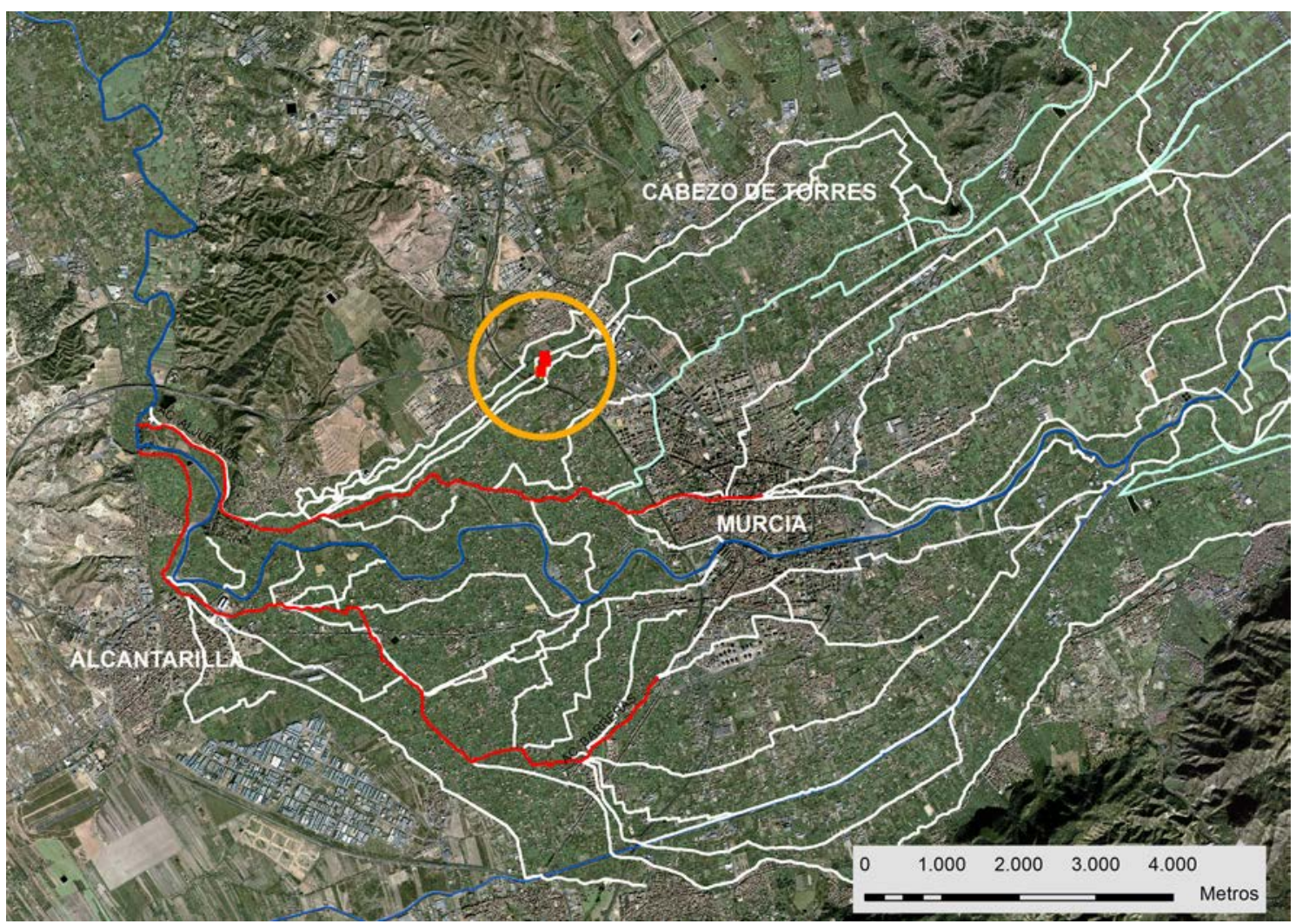

Figura 13. Localización de Senda de Granada en el sistema hidráulico andalusí de Murcia. En rojo, las acequias madre (norte, Aljufía y sur, Alquibla o Barreras); en blanco acequias (aguas vivas); en cian, los azarbes (aguas muertas); en azul, río Segura.

con toma directa en el río aguas arriba de Aljufía. Y culmina, en las postrimerías de su desarrollo, con la prolongación de algunos cauces como el de la acequia mayor de Aljufía que al sobrepasar la medina cambia su nombre por el de Benetúcer, testimonio de un segundo impulso constructivo (POCKLINGTON, 1990: 164, 194).

A su vez R. Pocklington, atendiendo a la configuración topográfica de la huerta murciana, con un valle intermedio entre el río y las sierras que flanquean la vega, propone para el caso de Murcia la existencia de una doble acequia madre encargada de regar las respectivas márgenes de esta micro-cuenca interior, identificando Aljufía y Alfatego como cauces gemelos en el heredamiento norte (POCKLINGTON, 1990: 160-165) (teoría de la doble acequia mayor).
En otro orden se podría considerar un tercer modelo constructivo para el sistema hidráulico andalusí murciano, según el cual "en primer lugar aparecen un importante número de cauces de longitud reducida que riegan extensiones no muy amplias y estables desde fechas antiguas" (GARCÍA CALVO-TORNEL, 1975: 142). La acequia mayor del sistema de riego discurriría por la cota más elevada posible -en nuestro caso Churra la Vieja o Alfatego- al objeto de facilitar la expansión de la red hídrica y del espacio agrario, bajo el estricto criterio del riego por gravedad68 (teoría de la rigidez).

En cualquier caso aún no estamos en condiciones de afirmar la prevalencia de ninguna de estas hipótesis sobre el modelo constructivo en el heredamiento Norte, dada la inexistencia de intervenciones arqueológicas

68 Esta propuesta contradice la asentada tesis que considera Aljufía como la acequia Mayor del Norte, reafirmada por su trayecto cercano a la medina islámica. 
en la acequia mayor de Aljufía (toma, cauce, partidores, etc.), que permitan deducir la fecha de su construcción: anterior, simultánea o posterior respecto de Churra la Vieja o Alfatego ${ }^{69}$.

No obstante, la datación temprana en el siglo X que aportan tanto los arcaduces de amarre próximo-distal de cuerpo cónico y engrosamiento basal, como la fábrica de mampostería en espiga del pozo de la aceñas 1 y 3,-fecha que no se circunscribe sólo a Churra la Vieja (aceña 1) sino también al tramo antiguo de Alfatego (acequia del Tablacho) (aceña 3) (GARCÍA BLÁNQUEZ, 2014), si nos invita a replantear la interpretación de este proceso.

Históricamente el comienzo de la configuración del sistema hidráulico andalusí murciano cabe situarlo -tras la fundación de mādinat Mursiya ordenada por 'Abd Al-Rahmān II (822-852) en el año 825- entre finales de esta centuria (s. IX) y el período de estabilidad política y militar sucedido en el siglo siguiente (s. $X$ ) -durante los reinados de 'Abd Al-Rahmān III (929-961) o Al-Hakam II (961-976)-, aunque algún autor desestima, incluso, que este tuviera lugar antes del siglo XI (ROBLES FERNÁNDEZ, 2006: 9), fecha en la que el geógrafo árabe al-'Udrī (s. XI) menciona por primera vez su existencia.

Al-'Udrī, en su relato Tarsī' al-Ajbār (c. 1075) nos revela la existencia de una sola acequia: "El comienzo de la acequia (sāqiya) que parte del río está en QantaratAskāba (actual Alcan- tarilla), y alcanza las propiedades de los habitantes de la ciudad (madinna) de Mursiya, hasta el límite territorial de alquería de $\operatorname{Twas}^{70}$, que es una de la alquerías de la ciudad (madina) de Orihuela (Uryūla)" (MOLINA LÓPEZ, 1972: $44)^{71}$.

La primera referencia a las dos acequias mayores nos la ofrece Al-Himyarī, autor del s.XIV/XV, aunque los datos que maneja en su obra (Al-Rawd al-Mi'tār) son descripciones de autores anteriores a la Conquista castellana (1243). Menciona que el tramo de Mediodía está formado por un qanat de una milla de longitud y el del norte por otro similar de dos millas de longitud: "... Ambos canales tienen respiraderos en lo alto de sus respectivas montañas, y aliviaderos que salen en dirección al río, mediante cuya apertura, y el descenso rápido del agua, los dos canales se limpian de todos los materiales de arrastre que se hayan acumulado en ellos ..." (POCKLINGTON, 1990: 151).

Hasta ahora la ausencia de datos arqueológicos que se puedan relacionar con el momento "fundacional", hacía que el análisis de las fuentes árabes fuera el único recurso disponible para dilucidar cuándo y cómo se puso en marcha el regadío en Murcia. Afortunadamente también disponemos ahora, aunque de forma indirecta, de la datación arqueológica que acota terminus ante quem los hechos históricos referidos por las fuentes. En consecuencia, los nuevos indicadores cronológicos obtenidos en Senda de Granada

69 La intervención arqueológica en el sistema hidráulico murciano es imprescindible para dilucidar todos aquellos aspectos que las fuentes árabes y cristianas no pueden resolver por sí mismas. La experiencia adquirida en Senda de Granada, pone de manifiesto que los tímidos intentos de catalogar superficialmente las estructuras hidráulicas actuales que llevó a cabo la administración murciana, carecen de sentido si no se acompañan de intervenciones arqueológicas. Autorizar en la década de los noventa del siglo pasado la destrucción de la mayor parte del trazado inicial de las acequias mayores (Aljufía y Alquibla) sin las correspondientes excavaciones arqueológicas o el mínimo seguimiento técnico de la destrucción de su cauce histórico, ha sido un error lamentable que habrá causado pérdidas irremediables. A día de hoy este problema no se ha subsanado y se sigue permitiendo el entubamiento, el traslado o supresión de las antiguas acequias andalusíes. El sistema de riego de la huerta de Murcia constituye el único monumento histórico con mil años de antigüedad "vivo" que tiene Murcia, y se le está haciendo desaparecer eliminado su parte esencial: la red de acequias y su entorno. Es necesario, pues, desarrollar de forma urgente una política preventiva que evite la pérdida y destrucción, no solo del registro arqueológico, sino del propio yacimiento histórico que es la huerta de Murcia en toda su extensión y los elementos que los caracterizan.

70 A. Carmona y R. Pocklington (2008: 49) siguen la interpretación propuesta por J. Vallvé (1986: 160) de leer Kawš (actual Cox, Alicante) en lugar del nombre Taws.

71 R. Pocklington (1990: 150) traduce el mismo pasaje: “El comienzo de la acequia que se toma del río está en Qantarat Askāba (actual Alcantarilla). Esta acequia atraviesa las propiedades de los habitantes de la ciudad de Murcia hasta alcanzar el límite de la alquería de Taws, perteneciente a la jurisdicción de Orihuela". 
requieren, pues, nuevas interpretaciones y, en este sentido, cabe conjeturar varios supuestos relativos a la "creación" (o puesta en marcha) del sistema de irrigación andalusí murciano y su desarrollo posterior.

Respecto de la creación del heredamiento Norte hemos de aceptar que si en el siglo $X$ las acequias Churra la Vieja y el tramo antiguo de Alfatego ya se encontraban plenamente operativas (GARCÍA BLÁNQUEZ, 2014), regando este sector de la huerta (con sus respectivos ingenios hidráulicos), su acequia mayor, pongamos por caso Aljufía, hubo de ser construida, indiscutiblemente, en un momento anterior.

Desconocemos la rapidez a la que progresaba la ejecución del sistema hidráulico murciano (diseño, replanteo sobre el terreno, apertura de canales, etc.) y cuantas etapas hubieron de acometerse hasta alcanzar su máxima extensión con la teórica apertura de Churra la Vieja, pero es muy probable que a finales del siglo IX o comienzos del X las obras de la acequia mayor estuvieran en marcha o a punto de concluir. Período (SS. IX-X) en el que se debieron redactar los textos que más tarde manejaría el autor almeriense (Al-'Udrī) para elaborar la descripción que conocemos (CARMONA y POCKLINGTON, 2008: 23); documentos que por su antigüedad sólo podían hacer referencia al estadio inicial del proyecto, razón por la cual menciona una sola acequia.

Por otra parte, siguiendo la teoría de R. Pocklington sobre la existencia de la doble acequia mayor, también es probable que los canales principales del heredamiento (Aljufía y Churra la Vieja y, poco después, Alfatego ${ }^{72}$ ) se ejecutaran de forma simultánea.
No obstante, sea como fuere, ambas posibilidades permiten considerar el tránsito entre los siglos IX y X, cuando menos, el momento de comienzo de la construcción del sistema de riego de Murcia; datación anterior a la propuesta por R. Pocklington (año 1000), autor con el que estamos de acuerdo, en cambio, sobre la razonable hipótesis acerca del carácter progresivo de su construcción, tanto de la acequia madre de Aljufía como del conjunto del sistema hidráulico en general (POCKLINGTON, 1990: 155, 164).

En relación con esto, el texto de Al-'Udrī encierra además otra posible clave cronológica que creemos sustenta nuestra tesis sobre el precoz desarrollo del regadío andalusí murciano. Nos referimos a la extremada longitud de la acequia que menciona, con término en la alquería de Taws/Kawš perteneciente a la jurisdicción de Orihuela. Según esto se puede inferir que en el siglo XI el heredamiento norte había alcanzado su máxima extensión y, por ello, se había procedido a una nueva expansión, hecho que se constata con su prolongación y el cambio de nombre de algunas acequias tras sobrepasar la medina ${ }^{73}$, límite probable del primer impulso constructivo. La descripción del geógrafo resulta interesante por cuanto hace referencia simultáneamente al momento inicial (una sola acequia) al mismo tiempo que alude a la ampliación consumada del sistema hidráulico (prolongación de Aljufía hasta Orihuela), sin mencionar aún ni la existencia del azud ni la duplicidad de los heredamientos con su gran extensión.

Según esto, atendiendo a las fuentes y a la datación arqueológica obtenida en Senda de Granada, podríamos acotar temporalmente este proceso y esbozar la siguiente propuesta

72 El tipo de riego a portillo (toma abierta) que ostenta Churra la Vieja (MANCHA, 1836: p. 27) ha de ser considerado indicio claro de mayor antigüedad respecto de la acequia Alfatego con riego de toma cerrada, es decir, sometido a tanda. La disposición de agua en los primeros canales hacía innecesario repartirla, de modo que los usuarios disponían de ella tanto como necesitaran. Posteriormente las sucesivas ampliaciones de los regadíos obligaron a repartir el agua estableciendo tandas de riego, determinando el día, las horas y los minutos que podía regar cada uno (MANCHA, 1836: p. 21). El tipo de riego de la acequia Alfatego y la datación arqueológica de las aceñas (n. 1 y 2) y los arcaduces documentados permiten considerar que su construcción fue, cuando menos, simultánea a Churra la Vieja, si no posterior.

73 La acequia mayor de Aljufía en el límite de la ciudad, a partir de la Puerta Nueva, pasa a llamarse Benetúcer. 
sobre el desarrollo del sistema de riego mursí: hacia finales del siglo IX o principios del X se acomete en el heredamiento Norte la apertura de una acequia mayor cuyo cauce primigenio podríamos identificar, quizás, con alguno de los canales rupestres que se conservan actualmente en el complejo de la Contraparada; posteriormente, pero en un momento previo a la noticia de Al-'Udrī (c. 1075), se consigue un incremento de caudal (aumento de capacidad de las aceñas 2 y 3) que permitiría ampliar la superficie irrigada con nuevos canales y prolongar las acequias más allá de la medina, hecho que podríamos relacionar con una hipotética mejora o traslado hacia un lugar más favorable (aguas arriba) de la toma de esta acequia mayor; finalmente, en las postrimerías del siglo XI o comienzos del $X I I$, con el represamiento total del río con un azud se logra un nuevo aumento de caudal y la apertura de la acequia mayor de Alquibla (o Barreras), momento en el que se pone en riego el heredamiento de Mediodía.

En definitiva las aceñas y los arcaduces de Senda de Granada, como decíamos, han proporcionado una datación relativa acerca de la creación del sistema hidráulico murciano, su desarrollo y su extensión en una determinada etapa, hechos que las fuentes árabes y cristianas no nos permitían precisar. No ha sido hasta ahora, pues, cuando se ha dispuesto del registro arqueológico material para comprender el proceso de formación de este sector del heredamiento Norte, verificar su extensión y datarlo en el siglo X, hecho de gran relevancia que permite determinar terminus ante quem la "fundación" del sistema hidráulico andalusí murciano. Fecha que invita, a su vez, a descartar la interpretación del modelo de desarrollo generalmente admitido -la ramificación de la acequia mayor de Aljufía- en pro de las otras dos teorías más acordes cronológicamente con la datación obtenida (s. X), cuya antigüedad resultaría incompatible con un supuesto proceso de expansión que situaría el área que estudiamos en el último estadio evolutivo.

\section{FUENTES}

AL-'UDQR̄̄, Al-masālik ilā gamī‘ al-mamālik; Al Ahwani (ed.), Fragmentos geográfico históricos de Al-masālik ilā gamī‘ al-mamālik, Madrid, 1965; E. Molina López (trad.), La Cora de Tudmīr según al-'Udrī (s. xi). Aportaciones al estudio geográfico descriptivo del SE peninsular, «Cuadernos de Historia del Islam», 4; serie monográfica, no 3, 1972.

IBN AL-AWWĀM, Libro de agricultura (ed. y trad. J.A. Banqueri; estudio preliminar y notas de J.E. Hernández y E. García), 2 vols., Madrid, 1988 (ed. Facsímil de 1802).

ISIDORO DE SEVILLA, Etimologías (Etymologiae - Originum sive etymologiarum libri viginti), OROZ RETA, J., MARCOS CASQUERO, M. A. (eds.), ed. bilingüe, Madrid, 1982 B.A.C.

VITRUVIO POLIÓN, MARCO, Los diez libros de Arquitectura (De Architectura). Editorial Alianza. Madrid, 2009

CARMONA-POCKLINGTON (2008: 59), recogen este texto de 'Abdallāh al-Hiğārī que cita Ibn Sa'īd al-Magribī en su Mugrib fĩ hulà I-Magrib, en el que compara los ríos de las ciudades hermanas de Sevilla y Murcia.

\section{BIBLIOGRAFÍA}

ACIÉN ALMANSA, M., MARTÍNEZ MADRID, R., (1989): "Cerámica islámica arcaica del sureste de al-Andalus", Boletín de Arqueología Medieval. Madrid, 3.

AL-HASSAN, R., HILL, D.R. (1986): Islamic Technology: An Illustrated History, Cambridge, UNESCO y Cambridge University Press.

AZUAR RUIZ, R. (1989): La rábita califal de las Dunas de Guardamar (Alicante). Cerámica. Epigrafía. Fauna. Malacofauna. Memorias del Museo Arqueológico Provincial. Diputación Provincial de Alicante. Alicante.

BARCELÓ PERELLÓ, M. (1989): "El diseño de espacios irrigados al-Andalus: un enunciado de principios generales", El agua en zonas áridas: Arqueología e Historia: I Coloquio de Historia y Medio Físico, Instituto de Estudios Almerienses. Departamento de Historia, Vol. I, p. XV-XLIX

BARCELÓ PERELLÓ, M. (1996): El agua que no duerme. Granada.

BALLESTEROS ARIAS, P.; EIROA, J.; KIRCHNER, H.; FERNÁNDEZ MIER, M.; ORTEGA ORTEGA, J.; QUIRÓS CASTILLO, J.A.; RETAMERO, F.; SITJES, E.; TORRÓ, J.; VIGIL-ESCALERA GUIRADO, A. (2008): "Por una arqueología agraria de las sociedades medievales hispánicas. Propuesta de un protocolo de investigación.” En HELENA KIRCHNER (Ed.) Por una arqueología agraria. Perspectivas de investigación sobre espacios de cultivo en las sociedades medievales hispánicas. BAR International Series 2062, 2010

BAZZANA, A. (1987): "Una noria árabe en la huerta de Oliva (Valencia)" I/ Congreso de Arqueología Medieval Española. Tomo II. Madrid. Pp. 421-432.

BAZZANA, A., CLIMENT, S., MONTMESSIN, Y., (1987): El yacimiento medieval de "Les Jovades", Oliva (Valencia). Ayuntamiento de Oliva, Oliva. 
BAZZANA, A.; MONTMESSIN, Y. (2006): Na'ura et saniya dans l'hydraulique agricole d'al-Andalus à la lumière des fouilles de "Les Jovades" (Oliva, Valence). En: CRESSIER, P. (ed.) La Maîtrise de l'eau en al-Andalus. Paysages, pratiques et techniques. Madrid, Casa de Velázquez, pp. 209-287.

BAZZANA, A., DE MEULEMEESTER, J. (2009): "La noria, l'aubergine et le fellah. Archéologie des espaces irrigués dans l'Occiddent musulman médiéval (9e-15e siècles)", Archaeological Reports Ghent Unviversity, 6, Gent (Bélgica), $498 \mathrm{p}$.

BELANDO Y MELENDEZ, J. (1878): Estudio sobre el río Segura y la huerta de Murcia. El Álbum, Murcia

BENABAT HIERRO, Y., PÉREZ MACÍAS, J.A. (1999): “La Ollita, una noria islámica en Niebla" Huelva en su Historia, 2a época, vol. 7, pp. 233-243.

BERTRAND, M., CRESSIER, P. (1985): "Irrigation et aménagement du territoir dans le vallée de l'Andarax (Almería): les réseaux anciens de Ragol", Mélanges de la Casa Velázquez, XXI, p. 115-135.

BERTRAND, M., CRESSIER, P. (1986): "Antiguos sistemas de irrigación en el valle de Andarax (Almería)" I Congreso de Arqueología Medieval Española. Zaragoza

BOLENS, L. (1972): "L' eau et l'irrigation d'après les traités d'agronomie andalous au Moyen Âge (Xle-XIle siècles)", Options Méditerranéennes, 16, pp. 65-77.

CALVO GARCÍA-TORNEL, F. (1975): Continuidad y Cambio en la Huerta de Murcia, Murcia.

CARA BARRIONUEVO, L. (1990): "La Remodelación de una fortaleza musulmana medieval: la Alcazaba de Almería en época cristiana (siglos XV y XVI)". Coloquio Almería entre culturas. Instituto de Estudios Almerienses, pp. 453-485.

CARMONA GONZÁLEZ, A. (1989) "Murcia ¿Una fundación árabe? (Nuevos datos y conclusiones)" Murcia Musulmana, p. $85-147$

CARMONA, A., POCKLINGTON, R. (2008): Agua e irrigación de la Murcia árabe. Murcia.

CARO BAROJA, J. (1954): "Norias, Azudas y Aceñas", Revista de Dialectología y Tradiciones Populares, X: 29-160

CARO BAROJA, J. (1955): "Sobre la historia de la noria de tiro", Revista de Dialectología y Tradiciones Populares, XI, CSIC, pp. 17-79.

CARO BAROJA, J. (1983): "Norias, Azudas y Aceñas", Tecnología Popular Española. Artes del Tiempo y del Espacio. Madrid, p. 239-407.

\section{Qadis). Universidad de Cádiz}

CRESSIER, P. (1989): "Archeologie des estructures hydrauliques en Al-Andalus", El agua en zonas áridas: Arqueología e Historia: I Coloquio de Historia y Medio Físico. Instituto de Estudios Almerienses. Departamento de Historia, p. LIII-LXXXVIII.

COLIN, G. S. (1932): "La noria marocaine et les machines hydrauliques dans le monde árabe" Hespéris, XIV, p. 22-60
DÍAZ CASSOU, P., (1879): Memoria sobre los riegos del Segura que, por encargo de la Comisión Representativa de Hacendados de la Huerta de Murcia. Murcia.

DÍAZ CASSOU, P., (1889): Ordenanzas y costumbres de la Huerta de Murcia / compiladas y comentadas por Pedro Díaz Cassou; con un estudio preliminar del Sr. D. Francisco Silvela de Levielleuze. Madrid.

FLORS UREÑA, E. (2009): "La fase andalusí de Torre La Sal y la superposición de los espacios” pp. 219-241. En FLORS UREÑA, E. (Coord.): Torre la Sal (Ribera de Cabanes, Castellón): Evolución del paisaje antrópico desde la Prehistoria hasta el Medioevo.

FORNEAS, J. M. (1974): "Un texto de Ibn Hišam al-Lajmī sobre las máquinas hidráulicas y su terminología técnica" Miscelánea de estudios árabes y hebraicos XXIII. BUSCAR

GARCÍA BLÁNQUEZ, L.A., 2010: "Senda de Granada: un asentamiento rural tardoantiguo en el entorno de Murcia" en NOGUERA CELDRÁN, J.M. (Ed.) Poblamiento rural romano en el sureste de Hispania.15 años después. Murcia 2010. P. 467-513.

GARCÍA BLÁNQUEZ, L.; CERDÁ MONDÉJAR, C. (2007): "Estructuras hidráulicas medievales: tres aceñas y un tablacho en las acequias Churra la Vieja y Alfatego. Senda de Granada (Murcia)". Revista Murciana de Antropología, 14, pp. 343-362.

GARCÍA BLÁNQUEZ, L. (2014): "Los arcaduces islámicos de Senda de Granada. Tipología y encuadre cronológico", Arqueología y Territorio Medieval, 21, Jaén. Pp. 69-103

GLICK, T.F. (1970): Irrigation and Society in Medieval Valencia. Massachusetts.

GLICK, T.F. (1977):“Noria Pots in Spain”. Technology and Culture, Vol. 18, № 4, pp. 644-650

GLICK, T.F. (1988): Regadío y sociedad en la Valencia medieval. Valencia.

GLICK, T.F. (1992): "Regadío y técnicas agrícolas en AlAndalus. Su difusión según un eje Este-Oeste", en Actas del I Seminario sobre la Caña de Azúcar. La Caña de Azúcar en tiempos de los Grandes Descubrimientos (1450-1550), Granada, 1990, pp. 83-98.

GLICK, T.F. (1992b): Tecnología, ciencia y cultura en la España medieval, Madrid, Alianza Universidad.

GLICK, T.F. (1999): Islamic and Christian spain in the early middle ages. Comparative Perspectives on Social and Cultural Formation. (Edición impresa: Princenton University Press, 1979)

GLICK, T.F. (2001): The Irrigation Communities of Medieval. Valencia

GUTIÉRREZ LLORET, S. (1986): "Cerámicas comunes altomedievales: contribución al estudio del tránsito de la antigüedad al mundo paleoislámico en las comarcas meridionales del País Valenciano". Lvcentvm, 5

GUTIÉRREZ LLORET, S. (1988): Cerámica común paleoandalusí del sur de Alicante (siglos VII-X). Alicante. 
GUTIÉRREZ LLORET, S. (1993): "La cerámica paleoandalusí del sureste peninsular (Tūdmir): producción y distribución" en MALPICA CUELLO, A. (Ed.) La cerámica Altomedieval en el sur de al-Andalus. Granada, p. 38-65.

GUTIÉRREZ LLORET, S. (1996): "El aprovechamiento agrícola de las zonas húmedas: la introducción del arcaduz en el sureste de Al-Andalus (siglos VIII y IX)", Arqueología y Territorio Medieval, 3. Universidad de Jaén, pp. 7-19.

GUTIÉRREZ LLORET, S. (1996): La Cora de Tudmir: de la antigüedad tardía al mundo islámico. Poblamiento y cultura material. Casa de Velázquez

JIMÉNEZ CASTILLO, P. (2001): Murcia islámica. Una visión a través de la arqueología. Ayuntamiento de Murcia.

JIMÉNEZ CASTILLO, P. (2013): Murcia. De la antigüedad al Islám. (Tesis doctoral inédita). Universidad de Granada. http://hdl.handle.net/10261/95860

KIRCHNER, H.; NAVARRO, C. (1993): "Objetivos, método y práctica de la arqueología hidráulica”. Arqueología y territorio Medieval, 1, (1994), pp. 159-182.

KIRCHNER, H. (2008): "Arqueologia hidràulica i tipologia d'espais irrigats andalusins." III Curs Internacional d'Arqueologia Medieval. La prospecció i el territori. LleidaAlgerri 13-14 de marzo de 2008.

LILLO CARPIO, M. (1989): "Morfogénesis y ocupación del territorio en el área donde se asienta la ciudad de Murcia”, en Homenaje de D. Luis Rubio. Estudios Románticos, VI, Murcia, 1986-1989, p. 1673 y ss.

LILLO CARPIO, P. A., (1999): "La vega del Segura, lugar de asentamiento de los primeros pobladores", Anales de Prehistoria y Arquoelogía de Murcia, pp. 121-140

MALPICA CUELLO, A. (1991): "El complejo hidráulico de los Albercones", Cuadernos de la Alhambra, 27, pp. 65-102

MALPICA CUELLO, A. (Ed.). (1993): La cerámica altomedieval en el sur de al-Andalus. Primer Encuentro de Arqueología y Patrimonio, 1991 Salobreña (Granada).

MALPICA CUELLO, A. (1995): "El agua en al-Andalus. Un debate historiográfico y una propuesta de análisis”. Pp. 65-86.

MALPICA CUELLO, A. (1995b): "Análisis arqueológico de las terrazas de cultivo el ejemplo de los Albercones de la Alhambra de Granada", Agricultura y regadío en alAndalus, actas del coloquio, Almería 9 y 10 de junio de 1995, pp. 409-424.

MALPICA CUELLO, A. (2002): "La Alhambra y su entorno: espacio rural y espacio urbano" Cuadernos de la Alhambra, 38, pp. 183-218. http://hdl.handle.net/10514/14195

MANCHA, R., (1836): Memoria sobre la población y riegos de la Huerta de Murcia, Imprenta de Mariano Bellido, Murcia.

MANZANO MORENO, E. (1986): "El regadío en Al-Andalus: problemas en torno a su estudio", En la España medieval, t. V. Editorial Universidad Complutense, pp. 617-632.
MARTÍ, R. (1989): "Oriente y Occidente en las tradiciones hidráulicas medievales", El agua en zonas áridas: Arqueología e Historia: I Coloquio de Historia y Medio Físico. Instituto de Estudios Almerienses. Departamento de Historia, p. 421-440

MOLINA LÓPEZ, E. (1972). "La Cora de Tudmīr según Al-'Ud dī (s. XI). Aportaciones al estudio geográfico descriptivo del SE peninsular". Cuadernos de Historial del Islam, no 3, Granada.

MONTANER SALAS, M.E. (1982). Norias, aceñas, artes y ceñiles en las vegas murcianas del Segura y Campo de Cartagena. Biblioteca Básica Murciana, 4. Ed. Regional de Murcia.

MURILLO, J. F., VENTURA, A.; HIDALGO, R.; BERMÚDEZ, J. M.; FUERTES, C.;

NAVARRO PALAZÓN, J. (1986): La cerámica islámica en Murcia. Volumen I: Catálogo. Murcia.

NAVARRO PALAZÓN, J. (1990): "Los materiales islámicos del alfar antiguo de San Nicolás de Murcia", en Fours de Poitiers et "testares" médiévaux en Méditerranée occidentale. Publications de la Casa de Velázquez, Série Archéologie XIII, p. 29-43

NAVARRO PALAZÓN, J., ROBLES FERNÁNDEZ, A. (1993): "El baño árabe de San Nicolás de Murcia" en Memorias de Arqueología, 4, (1990) p. 330-339

NAVARRO PALAZÓN, J., JIMÉNEZ CASTILLO, P. (1998): "Siyāsa: estudio arqueológico del despoblado andalusí (ss. XI-XIII)" en SALMERÓN, F., SALMERÓN, J. (Ed.), Materiales de Historia Local. Cieza. P. 99-113.

NAVARRO PALAZÓN, J., JIMÉNEZ CASTILLO, P. (2003): "La cerámica andalusí de Siyâsa. Estudio preliminar" en Cerâmica Medieval e Pós-Medieval, métodos e resultados para o seu estudo, Actas das 3a Jornadas Tondela (Portugal), 1997, p. 103-123

NAVARRO PALAZÓN, J., JIMÉNEZ CASTILLO, P. (2007): Siyāsa: estudio arqueológico del despoblado andalusi (ss. XI-XIII). El Legado Andalusí.

NAVARRO PALAZÓN, J., JIMÉNEZ CASTILLO, P. (2008) "EI agua en la ciudad andalusí", en SOBRINO SIMAL, J., CERVERA POZO, L. (Ed.) $2^{\circ}$ Coloquio Internacional Irrigación, Energía y Abastecimiento de Agua: La Cultura del Agua en el Arco Mediterráneo. P. 147-254.

NAVARRO PALAZÓN, J., JIMÉNEZ CASTILLO, P. (2010): "EI agua en la ciudad andalusi" Actas del II Coloquio Internacional Irrigación, Energía y Abastecimiento de Agua: La Cutlura del Agua en el Arco Mediterráneo. P. 47-254

NAVARRO PALAZÓN, J., JIMÉNEZ CASTILLO, P. (2011): "Materiales y técnicas constructivas en la Murcia andalusi (siglos X-XIII)", Arqueología de la Arquitectura, 8, C.S.I.C., p. $85-120$.

NAVARRO PALAZÓN, J., JIMÉNEZ CASTILLO, P. (2012): "La gestión del agua en la ciudad andalusí: el caso de Murcia” en GÓMEZ ESPÍN, J. M., HERVÁS AVILÉS, R. M. (Coords.), Patrimonio hidráulico y cultura del agua en el Mediterráneo. Murcia, pp. 105-143. 
OJEDA CALVO, R. (2006): "La Rota del Museo de Huelva: apuntes sobre el origen, adscripción, uso y funcionalidad de una rueda para evacuación de agua hallada en Minas de Riotinto." Centro de Intervención del APH. Dpto. de Investigación. P. 11-39.

ORTIZ SOLER, D., MORALES SÁNCHEZ, R., LÓPEZ BUSTOS, F. (1993): "Ámbitos ocupacionales y áreas residenciales en la Alzaba de Almería. Primeros resultados de una intervención arqueológica", IV Congreso de Arqueología Medieval Española, T. II, pp. 103-113.

POCKLINGTON, R. (1985): "Acequias árabes y pre-árabes en Murcia y Lorca: Aportación toponímica a la historia del regadío", X Col.loqui General de la Societat d'Onomástica, Valencia. P. 462-473

POCKLINGTON, R. (1990): Estudios toponímicos en torno a los orígenes de Murcia. Biblioteca Murciana de Bolsillo, Academia Alfonso X el Sabio. Murcia.

POVEDA SÁNCHEZ, A. (2004): "Un estudio sobre las norias de sangre de origen andalusí: el caso de la alquería de Benassal (Castellón)", Historia Agraria, no 32. P 37-58

POZO MARTíNEZ, I. (1991). "Un baño privado islámico en la calle Polo de Medina (Murcia)". Verdolay, n 3, Murcia. Pp. 79-94).

POZO MARTíNEZ, I (1999): "Arqueología y arquitectura islámicas en el Monasterio de Santa Clara la Real (Murcia)", Catálogo de la exposición: Paraísos Perdidos. Patios y Claustros. Murcia, pp. 53-104.

RAMÍREZ ÁGUILA, J.A., MARTíNEZ LÓPEZ, J.A. (1996): "Hidráulica urbana de una madina agrícola. Murcia, siglos XI-XIII", Agricultura y regadío en al-Andalus: II Coloquio de Historia y Medio Físico, Almería, pp.133-150
ROBLES FERNÁNDEZ, A., NAVARRO SANTA-CRUZ, E., MARTÍNEZ ALCALDE, M. (2002):"Sistemas hidráulicos y transformaciones urbanas en el sector oriental de Mursiya. Informe preliminar de la intervención realizada en la Plaza de Las Balsas, no 15" Memorias de Arqueología, 10, pp. 534-551.

ROBLES FERNÁNDEZ, A. (2006): Ingenios hidráulicos en la Murcia árabe. Ayto. de Murcia.

ROSSELLÓ BORDOY, G., (1978): Ensayo de sistematización de la cerámica árabe en Mallorca. Palma de Mallorca.

ROSSELLÓ BORDOY, G. (1993): "Las cerámicas de primera época: algunas observaciones metodológicas" en MALPICA CUELLO, A. (Ed.) La cerámica Altomedieval en el sur de al-Andalus. Granada, p. 14-35.

ROSSELLÓ VERGER, V.M., CANO GARCÍA, G.M. (1974): "Un parcelario geométrico cuestionable: la Huerta y la ciudad de Murcia" Estudios sobre centuriaciones romanas en España.

SCHIØLER, T. (1973): Roman and Islamic Water-Lifting Wheels. Copenhague, Odense University Press.

SCHIØLER, T. (2012): http://www.kattler.dk/schiolers/uk/ index.html: Photo collection about water-lifting devices (Consultado: 21-04-2012)

TORRES FONTES, J.; CODOM II.

TORRES FONTES, J, (1975): El regadío murciano en la primera mitad del siglo XIV. Junta de Hacendados. Murcia.

TORRES FONTES, J. (1990): Repartimiento y Repoblación de Murcia en el siglo XIII. Murcia.

VALLVÉ, J. (1986): La división territorial de la España musulmana. Madrid 